\title{
Personal wealth interests of politicians and government intervention in the economy: The bailout of the U.S. financial sector
}

\author{
Ahmed Tahoun \\ London School of Economics \\ Houghton Street \\ London, WC2A 2AE, UK \\ A.M.Tahoun@lse.ac.uk \\ Laurence van Lent \\ Tilburg University \\ CentER for Economic Research \\ PO Box 90153, 5000 LE Tilburg, The Netherlands \\ [T] +31 13466 8288, [F] +31 134668001 \\ vanlent@uvt.nl
}

First draft: 1 February 2010

This version: 31 December 2010

Part of this research was undertaken while Ahmed Tahoun was a visiting scholar at the Wharton School and Laurence van Lent was a visiting fellow at the Initiative on Global Markets of the University of Chicago. We thank Arian Borgers, Chung-Yu Hung, Wim Janssen, and Miao Nie for able research assistance. We are grateful for helpful comments from participants at the VII Workshop on Empirical Research in Financial Accounting in Cartagena (Spain), the 2011 American Economic Association annual meeting, from workshop participants at the University of Amsterdam, the University of Mannheim, Lancaster University, LSE, Tilburg University, and from Vasiliki Athanasakou, Jennifer Blouin, Jannis Bischof, Sanjay Bissessur, Jan Bouwens, Christina Elschner, Luzi Hail, Christian Hofmann, Stephan Hollander, Harry Huizinga, Yuping Jia, Vicky Kiosse, Christopher Koch, Liisa Kurunmaki, Christian Leuz, Valeri Nikolaev, John O’Hanlon, Ken Peasnell, Martin Ruf, Wim Van der Stede, Ro Verrecchia, Arnt Verriest, and Yachang Zeng. Ahmed Tahoun acknowledges the financial contribution of the European Commission Research Training Network INTACCT (MRTN-CT-2006-035850). An earlier version of this paper was circulated under the title: "Equity ownership and campaign financing of members of Congress and the bailout of the financial sector”. 


\title{
Personal wealth interests of politicians and government intervention in the economy: The bailout of the U.S. financial sector
}

\begin{abstract}
We examine whether the incentives derived from equity ownership affect politicians' decisions about government intervention in the economy. We investigate this question in the context of the government's support to financial institutions under the Emergency Economic Stabilization Act (EESA). We find that the equity ownership of members of the House of Representatives, but not the Senate, is positively associated with voting in favor of key legislative proposals to bailout the financial sector. We show that the effect that equity ownership has on voting likely reflects a politician's personal wealth interests and is separate and distinct from other economic incentives that derive from constituent and special interests. In a sample of 555 publicly listed financial institutions, we also find that the equity ownership of Congress members seated on financial sector-related committees is positively associated with both the amount of bailout these institutions receive, as well as the timing of that bailout. We can attribute this finding to the investments of the chairpersons and ranking members of these committees.
\end{abstract}

Key words: financial crisis, bailout, politicians, investments, personal wealth, voting

JEL-code: D72, G11, G21, G22, G38 


\section{Personal wealth interests of politicians and government intervention in the economy: the bailout of the US financial sector}

\section{Introduction}

We examine whether the incentives derived from personal wealth affect politicians’ decisions about government intervention in the economy. Specifically, we consider whether the equity ownership of members of Congress affected their vote on legislative proposals to bailout the financial sector in the autumn of 2008. In addition, we ask whether the equity ownership of politicians in financial institutions is associated with the likelihood that these institutions will receive government support under the Troubled Asset Relief Program (TARP).

To our knowledge, ours is the first study to document the association between the equity ownership of members of Congress, on the one hand, and government intervention and regulatory actions, on the other. ${ }^{1}$ We examine the role politicians' equity ownership plays in the context of the U.S. government's intervention during the subprime mortgage crisis of 2007 and onward for two reasons. First, the amount of government intervention and money involved is unprecedented. Second, administration officials and regulators had substantial discretion over how to execute the intervention. Together, these facts create a setting ripe for politicking, influencing, and pressure activities involving politicians, regulators, firms, and other constituents (Stigler 1971; Tullock 1971; Peltzman 1976; Stigler 1976; McCormick and Tollison 1981; Veronesi and Zingales 2010). Moreover, the common sense of urgency prompted by the financial crisis likely further compromised the oversight and transparency of administrative decision-making (SigTarp 2009b). Under these circumstances, personal wealth incentives would likely be sufficiently strong to affect politician behavior in a manner observable to researchers.

In response to the deepening financial crisis, Congress passed the Emergency Economic Stabilization Act (EESA) on October 3, 2008, after a brief but complex congressional procedure. Under EESA, the Treasury was authorized to spend $\$ 700$ billion in an effort to stabilize financial markets and restore liquidity. Although Congress did not approve the Secretary of the Treasury's

\footnotetext{
${ }^{1}$ Ziobrowski, Cheng, Boyd, and Ziobrowski (2004), however, use personal finance data to examine the (abnormal) returns on investments held by senators.
} 
petition for exemption from judicial oversight, Secretary Paulson nevertheless wielded broad decision-making power within the Troubled Asset Relief Program (TARP), which was authorized by EESA. Specifically, EESA grants the Secretary of the Treasury discretion in determining which "troubled assets" to purchase, that is, which institutions to bail out. The Treasury's extensive authority and the sheer amount of money involved raised widespread concerns about possible conflicts of interest and misappropriations of government funds; nevertheless, the Secretary is required to make regular reports to Congress about these decisions and their impact. ${ }^{2}$ It is because Congress oversees the implementation of TARP that we can examine the role that politicians' personal wealth plays in these decisions. ${ }^{3}$

Prior work has argued that politicians make decisions in response to the interests of their voters (i.e., “constituent interests”) and pressure groups (i.e., "special interests”) in an effort to win (re)election (Barro 1973; Levitt 1996; Mian, Sufi and Trebbi 2010b). The premise in this line of work is that politicians are motivated by the desire to increase their net wealth and that obtaining, or remaining in, political office allows them to do so. Politicians can, however, also directly increase their financial wealth by making decisions on behalf of the many that at the same time benefit their own personal financial wealth. If standard economic reasoning applies to political life, then potential net wealth effects must explain, at least in part, politicians’ decision-making.

When evaluating the role of personal wealth in political decision-making, one important question is whether its effect is distinct (and empirically separable) from the economic incentives that

\footnotetext{
${ }^{2}$ See, e.g., http://citizensforethics.org/node/39976. The Special Inspector General for the Troubled Asset Relief Program (SIGTARP) published an audit report concluding that there is no evidence of undue external influence over TARP decisions. Indeed, the report describes a decision-making process that is grounded in accountingbased indicators of financial health and that provides little discretion to regulators (SigTarp 2009a). Nevertheless, in another report to Congress, the Special Inspector General cites the private concerns of senior government officials regarding the viability of some of the first nine financial institutions that, despite these concerns, received government support (SigTarp 2009b). Anecdotal evidence suggests that at least some of the recipients of government support considered it a boon: "An overwhelming majority [of surveyed executives from banks] saw the bailout program as a no-strings-attached windfall that could be used to pay down debt, acquire other businesses or invest for the future" (McIntire 2009).

${ }^{3}$ Consider, for example, the case of Senator Daniel Inouye (D-Hawaii), a co-founder of Central Pacific bank, whose equity stake in that bank in at the start of 2008 fell in the range of $\$ 350,000-\$ 700,000$. An article in the Washington Post describes how while the bank awaited the decision on its TARP application, it faced increased pressure by regulators to raise additional capital. Then, after a single phone call from one of the senator's aides to the FDIC's local office, the matter was referred to the FDIC's headquarters in Washington, which serves as the usual point of contact for Congress members. Shortly after the phone call, the Treasury department, approved Central Pacific's application, even though the bank did not meet the criteria for Federal investment. See: http://www.washingtonpost.com/wp-dyn/content/article/2009/06/30/AR2009063004229.html
} 
derive from constituent and special interests. Indeed, politicians may use their personal wealth to aid local businesses and communities with a view to gathering electoral support, and a given politician's equity ownership in firms may thus simply follow from their responding to constituents' needs or to industry pressure groups that help finance their next election campaign. We therefore include proxy variables in our empirical analyses that capture the incentives derived from constituent and special interests and conduct several tests that attempt to identify the effect of personal wealth incentives on political decision-making separately from other economic incentives.

We first document that the equity ownership that members of the House of Representatives (but not of the Senate) hold in publicly listed financial institutions increases their probability of voting for key legislative proposals to bail out the financial sector while controlling for constituent and special interests. The effect is large; in the initial House vote, the predicted probability of voting in favor of the proposal is 42 percent for non-investors as compared to 60 percent for equity owners. Consistent with earlier work, we measure constituent interests by the importance of the financial sector to a politician's home state in terms of employment and we proxy for a politician's incentives to respond to the special interests from the financial service industry by the campaign donations he or she receives from the financial sector (Mian et al. 2010b). We show that the effect of equity ownership on voting for EESA can be attributed to the expected losses of representatives due to the financial crisis. We measure the expected losses by computing for each politician the realized stock returns on their portfolio of financial sector investments on the day that the House rejected the first bailout proposal. What is more, we show that the sensitivity of a given representative's wealth to the performance of the financial sector prior to the vote was significantly positive for those members who favored the bailout proposals, but not for those who voted against them.

We document that these wealth effects are economically meaningful; for example, a 10 percent decrease in the performance of the financial sector reduces the wealth of a given representative who voted in favor of bailout with about $\$ 300,000$. At the same time, however, representatives tend to be very wealthy individuals and the amounts involved might raise the question why politicians would want to go against constituent or special interests to recover a relatively small proportion of their personal wealth. Nevertheless, similar behavior has been documented in the 
context of executives committing white collar crimes (Levitt and Dubner 2005; Levitt 2006; Bhattacharya and Marshall 2009) inasmuch as the pecuniary gains from such acts also tend to be small compared to the wealth of these managers. ${ }^{4}$

We also show that it is the representatives' investments in financial institutions headquartered outside of their home states that explain their vote. Whereas home state investments may partially measure a politician's support for their local community and thus reflect constituent interests, out-ofstate investments have no direct relation to the interests of the politician's electorate and, rather, are a proxy for the economic incentives to be derived from personal financial wealth. Thus, our evidence is consistent with personal wealth interests, rather than constituent interests, explaining politicians' voting behavior. We then show that these economic incentives of equity ownership explain voting irrespective of the politician's ideological position on government intervention in the economy, except for the most conservative politicians. This finding is consistent with prior work, which has shown that in this Congressional vote, ideology can be a means for politicians to commit against succumbing to pressures from constituents and special interest groups (Mian et al. 2010b). We add to this result by showing that politicians can commit against intervention incentives that derive from personal financial wealth, but only if they adopt the most conservative ideological position.

Next, we document that, in the same sample of publicly listed financial institutions, the equity ownership held by Congress members seated on committees with jurisdiction over TARP is positively associated with these institutions receiving support, the amount of support received, and the timing of its receipt. Importantly, the equity ownership in financial institutions of non-committee members does not explain support decisions. We also show that the association between equity ownership of committee members and TARP support of financial institutions is not driven by the investments of committee members in their home state or by the number of committee members from the state wherein the firm is headquartered. We thus conclude that the equity ownership of committee members captures personal wealth incentives and does not reflect their support for the local community or other constituent interests. Furthermore, we can attribute this committee-level association to the equity

\footnotetext{
${ }^{4}$ Levitt and Dubner (2005, p. 50 ) speculate whether “cheating” is due to a given executives' overdeveloped sense of entitlement or because morally risky behavior is what makes managers successful in the first place.
} 
ownership of powerful members (i.e., (sub)committee chairpersons and ranking members) more than to the ownership of other committee members. These findings reduce the concern that the association between bailout decisions and politicians' equity ownership is driven by not properly accounting for underlying factors that explain why politicians hold ownership in firms. Indeed, if this were the case, we should not find that it is only the equity ownership of those members of Congress who can effectively influence intervention policy (i.e., the abovementioned (powerful) committee members) that matters.

Our results speak to a long-standing discussion in the political economy literature about what motivates politicians. One side of the debate sees politicians as "persons of character" who seek public office to change policy in the public interest. The opposing side holds that politicians, like any other economic agent, seek to further their own narrow self-interest as measured by their net wealth (Buchanan 1989). ${ }^{5}$ If politicians are motivated by a desire to change policy, then their net wealth should neither explain their vote on EESA nor affect the subsequent bailout decisions, once special and constituent interests are taken into account. If, on the other hand, politicians follow their narrow self-interest, then equity ownership should explain politicians' decision-making. Our results suggest that senators are more likely to be "persons of character", that is, motivated by policy change, than are members of the House. Indeed, when voting on EESA, while personal financial interests do not explain the vote in the Senate, they are significant in explaining the vote in the House of Representatives. ${ }^{6}$ That said, in the oversight of the allocation of TARP support to individual firms, the financial interests of both senators and representatives in the finance-related committees matters.

Before we continue, we would like to emphasize that finding an association between ownership and bailout decisions does not, in itself, constitute evidence of illegal or improper behavior on the part of Congress members. Indeed, Federal law defines a conflict of interest quite narrowly,

\footnotetext{
${ }^{5}$ See, e.g., the discussion in Belsey (2004). Wittman (1977) and Alesino (1988) offer models in which politicians are motivated by the desire to change policy. Callandar (2008) analyzes electoral competition between two types of agents, those who are motivated by the perks of political office and those who want to implement certain policies. In addition, Diermeier et al. (2005) show evidence that policy motivations at least partially explain the behavior of politicians. Ferraz and Finan (2008) argue, in contrast, that monetary rewards are the principal motivation for politicians.

${ }^{6}$ Compare this finding to Diermeier et al. (2005) who also find that senators are more motivated by policy change.
} 
and, in general, cases in which politicians support a decision that yields personal financial benefits do not qualify as conflicts of interest as long as the decision benefits many, and not just the member in question (Committee on Standards of Official Conduct 2008). ${ }^{7}$ Specifically, “ownership of stock in a publicly traded company generally will not present a conflict of interest requiring recusal from voting” (Committee on Standards of Official Conduct 2009, p. 11). Nevertheless, as House Speaker Ms. Pelosi has argued, “when there’s been a thought of conflict of interest between a member's financial holdings and government bailouts then that member should divest.”8

On a related note, Duchin and Sosyura (2009) show that Treasury purchases of preferred stock in banks under TARP's Capital Purchase Program are positively related to campaign contributions and firm representation at the Federal Reserve via board members. The authors also demonstrate that a given firm's lobby expenditures and donations to House members of the Financial Services committee are related to the amount of bailout funds committed to that firm. ${ }^{9}$ Mian, Sufi, and Trebbi (2010b) show that campaign donations of the financial sector and the economic interests of a politician's constituents are associated with the vote on the EESA bill. While covering shared terrain, our study differs from these papers in several essential ways. The most important difference is that we focus on the equity ownership of Congress members and its role in decisions about government intervention. Equity ownership provides important economic incentives that partially explain the voting behavior and oversight activities of members of Congress, and that are incremental to those provided by campaign donations and constituent interests.

\section{Related literature and institutional background}

\subsection{Government intervention in the economy}

\footnotetext{
${ }^{7}$ The House Ethics manual (2008) states "Some conflicts of interest are inherent in a representative system of government, and are not in themselves necessarily improper or unethical. Members of Congress frequently maintain economic interests that merge or correspond with the interests of their constituents. This community of interests is in the nature of representative government, and is therefore inevitable and unavoidable. At the other extreme, a conflict of interest becomes corruption when an official uses his position of influence to enhance his personal financial interests.” (p. 251)

${ }^{8}$ http://firstread.msnbc.msn.com/archive/2009/06/11/1962038.aspx Indeed, Ms. Pelosi herself fully divested her holdings in AIG on December 31, 2008, after AIG was bailed out in September.

${ }^{9} \mathrm{Li}$ (2010) finds that a financial institution's political connections, secured via donations, and representation on the board of the Federal Reserve affects the amount of bailout funds committed thereto and, in addition, shows that TARP funding increased loan growth for banks. Through an event study, Bayazitova and Shivdasani (2009) document positive announcement effects when a bank is approved for a TARP infusion.
} 
Corporate bailouts, taxation benefits, and the facilitation of access to cheap sources of financing have been identified as instruments of intervention politicians might use to distribute favors to firms (Khwaja and Mian 2005; Faccio, Masulis and McConnell 2006; Claessens, Feijen and Laeven 2008). In the banking sector specifically, the evidence from emerging economies is also consistent with politicians intervening in bank failures for electoral reasons, that is, for ensuring voter support (Brown and Dinc 2005). Thus, both constituent and special interests have been linked in prior work to government intervention. We are not aware, however, of any studies that have examined how individual politicians' ownership (as opposed to the ownership held in firms by the state, see Dinc (2005)) affects government intervention.

A related vein of literature, however, considers the advantages to firms of being connected to politicians. The most common measures of connection used in these studies are lobby expenditures, campaign donations, and politically connected board members. All of these measures, however, pertain to firm-initiated connections, and can thus perhaps be better thought of as measures of the special interests vying for the politician's attention. Firms and politicians also become connected when politicians invest in a firm's equity and become an (partial) owner. While politicians stand to gain from receiving firm support in the form of campaign donations or employee votes, their interests become even more closely aligned with those of firms when they become equity owners. Both as an equity owner and as a recipient of a particular firm's support during elections, a politician has a direct stake in the financial health and survival of that firm. Nevertheless, despite the availability of personal finance data in the United States, which we describe in detail below, the incentives that derive from ownership ties between firms and politicians have yet to receive much attention in the literature.

Several recent studies, most of which use the event study methodology, investigate the value of firms' political connections. These include studies that examine the effect on the value of connections following changes in Senate control (Jayachandran 2006), presidential elections (Knight 2006), the appointment of politically connected board members (Faccio 2006; Goldman, Rocholl and So 2009), and news of the sudden death or deteriorating health of politicians (Fisman 2001; Fisman, Fisman, Galef and Khurana 2006; Leuz and Oberholzer-Gee 2006). Cooper et al. (2010) examine firm-level campaign donations to politicians over an extended period and find that their measures of 
firm support are associated with future stock returns, particularly for House candidates and Democrats. In contrast, Aggarwal, Meschke, and Wang (2009) argue that donations provide firms with few benefits and more likely indicate agency problems. Yu and Yu (2008), however, find that firms that make substantial donations to political campaigns can postpone the detection of fraud, and Correia (2009) documents that firms' campaign donations and lobby expenditures can reduce their likelihood of being investigated by the SEC. Goldman et al. (2008) find that firms with boards connected to the winning (losing) party in presidential elections are more likely to experience an increase (decrease) in the value of government contracts. Finally, Benmelech and Moskowitz (2010) show that a firm's political connections can reduce their degree of competition in markets. The collective evidence in these studies suggests that politicians tend to respond to special interests, rendering "political connections" valuable to the firm. Thus, to distinguish between the incentives that derive from political ownership in firms and the incentives of firms' other political connections, we control in our empirical work for those alternative mechanisms that bind the fate of firms and politicians together.

\subsection{Voting in Congress}

A question that has been the subject of much debate in prior studies is whether members of Congress "die in their ideological boots" (Poole 2007), that is, whether they vote according to their (stable) political ideology or respond to the economic incentives that the interests of their electorate or their particular constituency provide (Peltzman 1976; Peltzman 1984). Indeed, it is reasonable to regard both as important determinants of the voting behavior of politicians (Kau, Keenan and Rubin 1982; Kalt and Zupan 1984; Levitt 1996). Prior work suggests that rational politicians who care about being reelected to office respond to the interests of their electorate (Kau et al. 1982). In addition, businesses, unions, and other groups can contribute financially to the campaigns of politicians, and as such affect the probability of their election. In turn, politicians respond to the needs of these special interest groups by voting in accordance with these groups' positions especially on issues with low salience to the electorate (Kroszner and Stratman 1998; Stratmann 2002).

Mian, Sufi, and Trebbi (2010b) examine the role of economic incentives in the congressional voting on EESA and conclude that members of Congress respond to the interests of both their electorate and the financial sector. That said, neither these authors nor the prior literature on 
congressional voting consider the incentives that arise from the personal wealth of politicians. Nevertheless, a politician's personal finances can benefit from how they vote on legislation involving a redistribution of wealth from tax payers to the firms in which they own a stake. Given the legal limits on campaign financing in the United States, the effect on a politician's personal wealth of favoring firms in which they own equity may outweigh that of favoring firms that contribute to their election campaigns. Thus, we predict that the equity ownership of members of Congress provides an economic incentive important enough to explain their voting beyond the incentives from constituent or special interests.

A politician’s ideology may help to mitigate pressures from constituents or special interest groups to redistribute wealth. Mian et al. (2010b) provide evidence that politicians with a conservative world view, that is, those who oppose government intervention in the economy, are more likely to resist an increased demand for intervention from their voters or from the financial sector. It is, however, a priori unclear whether ideology will also work as a commitment device against succumbing to the incentives derived from personal finances.

\subsection{Congressional committees}

Congressional committees set the agenda for the full House and Senate and wield considerable influence over the bureaus they monitor (Weingast and Moran 1983). In fact, overseeing the implementation of public policy falls most commonly to the standing committees of Congress (Kaiser, Oleszek, Halstead, Rosenberg and Tatelman 2007). Through their oversight, committee members can influence regulators and branches of the Executive under their jurisdiction (Weingast 1984; Kroszner and Strahan 1996). Kroszner and Stratmann (1998) describe the committee structure of Congress as an institutional arrangement that allows interest groups and legislators to engage in an enforceable long-term relation in which politicians receive donations that help them get reelected and interest groups obtain favorable legislative outcomes or benefit from committee members exerting pressure over regulatory agencies. As such, these authors empirically document that campaign contributions from the financial services sector are concentrated in the House Banking committee (rather than with non-financial-committee members) and that contributions increase when contributors expect to have an ongoing relation with a politician. Little attention, however, has been 
paid to the question how different interests compete at the committee level and especially to what the relative importance is of the personal financial wealth of committee members.

\subsection{Powerful politicians}

The political science literature acknowledges that senior politicians (i.e., those of relatively long tenure) have more influence over the legislative process than junior politicians do. This occurs, in part, because senior members are more likely to be appointed to important committees and serve as chair or, if their party is not in the majority, as ranking member. The chair determines the committee's agenda, decides when to take or delay action, presides over meetings, and controls most committee funds. The ranking member, usually the member of the minority party with the longest committee service, often helps the chair to regulate the committee and takes the lead on matters affecting the other minority members. In addition, each subcommittee has its own chair and ranking minority member (Schneider 2003). Cohen, Coval, and Malloy (2009) demonstrate that when a politician becomes chair, Federal spending in their home state increases. Likewise, Roberts (1990) finds a positive relation between committee seniority and the geographical distribution of Federal spending. Powerful politicians also tend to attract more campaign donations (Grieg and Munger 1991; Romer and Snyder Jr 1994; Ansolabehere and Snyder Jr 1999).

\subsection{Implications for the 2008 government intervention in the financial crisis}

Corporate bailouts are a significant form of government intervention. Policy makers have the power to affect the wealth of constituents; firms stand to make substantial financial gains by influencing government decision-makers; and elected officials can secure legislative outcomes that benefit contributors to their campaigns, voters, and/or their own personal finances. During the financial crisis, politicians had the chance on two separate occasions to shape the amount and direction of government intervention. The first occasion was the successions of roll calls in the House of Representatives and the Senate on the EESA. We predict that members of Congress who had ownership in financial sector firms were more likely to vote in favor of the proposals to bailout the sector. The second occasion came during the implementation of TARP. The Treasury department's decisions on TARP were subject to oversight from congressional committees. Members seated on these committees, therefore, could use their influence to benefit certain firms over others. Within 
these committees, it is the chairpersons and ranking members that exercise control over legislation and oversight. Thus, these members are in the best position to influence bailout decisions. The committees' decisions are likely to affect the personal wealth of their members - and thus we expect the incentives deriving from ownership in financial sector firms to matter in the decisions these committee members make. While prior literature (as summarized above) suggests that incentives that derive from special interests are particularly evident at the committee-level, we expect to find that the personal wealth of committee members has a separate and distinct effect on their decisions regarding the bailout.

\section{Sample selection and firm characteristics}

We are interested in the population of publicly traded financial institutions that were affected by the liquidity crisis of 2008. Because our primary interest is the effect politicians' equity ownership has on government interventions, we limit our sample to publicly listed firms trading on NYSE, Amex, or NASDAQ. We restrict our sample to these exchanges because hand-collecting data on the equity ownership of Congress members, on campaign finance donations, and on the sample firms' board memberships is too time consuming to support an even larger sample.

We include in our sample, banks, savings associations, bank-holding companies, and savings and loan-holding companies (SIC 6020-6036). While we include life insurance companies (SIC 6310-6319)—who, as members of the American Council of Life Insurers, collectively applied for consideration under TARP—we exclude property-casualty insurers, who, through the American Insurance Association, issued a public statement that they would not seek government support. ${ }^{10}$ We interpret these industry-wide choices as evidence that the liquidity crisis affected the life insurance industry more severely than the property insurers (who, while still affected, did not suffer to the same extent). The Treasury Secretary indicated early on, in October 2008, that only companies with Federal regulatory oversight would be considered for support (Andrews and Dash 2008). Nevertheless, we include all life insurance companies in our sample, irrespective of whether they already owned a federally chartered bank or were in the process of obtaining thrift status, because the Treasury allowed these firms to simultaneously apply for support and acquire a federally regulated bank.

\footnotetext{
${ }^{10}$ http://www.aiadc.org/aiadotnet/docHandler.aspx?DocID=318331
} 
We consider firms in the financial sector that received government support under any of the programs belonging to the Troubled Asset Relief Program. ${ }^{11}$ TARP authorizes the Secretary of the Treasury to purchase "troubled assets" from any financial institution that is established and operating under Federal or State law and has significant operations in the United States. Some TARP programs apply more restrictive eligibility criteria. Indeed, the Capital Purchase Program excludes U.S. subsidiaries and U.S. branches of foreign banks but admits life insurance companies that own federally chartered banks (usually a thrift). ${ }^{12}$ These differences between programs suggest that a given company's eligibility to benefit from a particular TARP program is itself a regulatory or political decision and is potentially a function of equity ownership, campaign contributions, and constituent pressures. We therefore cannot restrict our sample to financial institutions that are specifically eligible for certain TARP programs because doing so would introduce significant sample selection problems. $^{13}$

Our sample contains firms that publicly announced they would not seek TARP funding. ${ }^{14}$ We do not exclude these firms because their decision not to apply for funding may be conditioned on our variables of interest; for example, these firms may not count Congress members among their owners or they may not contribute to any politicians' election campaigns. If this were the case, to remove these firms would be to introduce a selection bias. We also determined whether a given firm made any public statements about declining to accept funding after the Treasury had deemed them eligible for TARP support. ${ }^{15}$ In these cases, we recorded the firm in our bailed-out category and used in our analysis the committed amount of bailout funds.

\footnotetext{
${ }^{11}$ We thus exclude any support committed to Fannie Mae and Freddie Mac, which falls under the Housing and Economic Recovery Act of 2008, as well as all TARP programs related to the automotive industry (i.e., the Automotive Industry Financing Program and the Auto Supplier Support Program).

${ }^{12}$ http://www.ots.treas.gov/. The decision to open the CPP program to life insurance companies that own federally chartered banks was announced on May 14, 2009. See, for example, Bloomberg News, May 15, 2009 : http://www.bloomberg.com/apps/news?pid=newsarchive\&sid=azvO_ChKZafg.

${ }^{13}$ Eligibility itself might follow from equity ownership or political donations. If we were to restrict our sample to financial companies eligible under specific TARP programs, we would possibly have overrepresented companies with higher levels of ownership or donations.

${ }^{14}$ Note that we deal differently with the industry association of property insurers' collective announcement and some financial institutions' individual announcement to refuse TARP funding. It is unlikely that the industry association of property insurers' collective decision not to apply for support derives from its membership's lack of political connections.

${ }^{15}$ We use Factiva to search for public announcements made by our sample firms. When a firm does not accept TARP support after being approved by the Treasury, we use as our bailout date the date of the earliest statement
} 
We require our sample firms to have data in the Center for Research in Security Prices (CRSP) and Compustat. Our final sample consists of 555 public financial sector firms, 295 of which received government support under the Troubled Asset Relief Program. We obtained from ProPublica.org data on the bailout amounts committed to each firm ${ }^{16}$ as well as the date the bailout was approved and verified the data against sources in the Treasury. ${ }^{17}$ For the latter, we used the date the contract between the Treasury and the financial institution was established, as indicated on the signature page of the letter agreement, which constitutes part of the contract, and considered the company's bailout status as of November 6, 2009. We obtained data on the political affiliation of members of financial firms' boards of directors from SEC filings of the definitive proxy statements (Form DEF14A).

All politician-level variables are computed for members of the $110^{\text {th }}$ Congress. We collect data on politicians' voting records from the Office of the Clerk of the House and the Senate Bill Clerk and on each Congress member's margin of victory in the most recent election from the public records of the Federal Election Commission. To measure the importance of the financial sector to each state, we gather employment data from the Bureau of Labor Statistics. To compute each politician's tenure in Congress, we use the date he or she was first elected, as provided by the Center for Responsive Politics. We use the first dimension of the DW-Nominate measure described in Poole and Rosenthal (2007) as our proxy variable for each politician's ideological position on government intervention in the economy. ${ }^{18}$ Finally, to determine each politician's committee membership in the $110^{\text {th }}$ Congress, we use data collected by Stewart and Woon (2009). ${ }^{19}$

Table 1 provides summary statistics on the financial characteristics of our sample firms, partitioned by bailout status. Univariate tests of differences between these subsamples are also reported. All variables in this table are Winsorized at the 1 percent level. We report both accounting-

that the firm was approved for funding. In 8 cases we could not find the approved bailout amount, and we dropped these firms from the analysis.

${ }^{16}$ The exact definition depends on the TARP program; within the CPP, we use the purchase price of the preferred stock as mentioned in the "terms of the purchase" section of the contract.

${ }_{17}$ Available at: $w w w$. financialstability.gov

${ }^{18}$ Available at: $\mathrm{http://voteview.com/dwnomin.htm}$

${ }^{19}$ Available at: $\underline{\text { http://web.mit.edu/17.251/www/data_page.html\#1 }}$ 
based and market indicators of financial health. ${ }^{20}$ We find that bailed-out firms are larger than their counterparts, with their average beginning market value of equity equal to $\$ 4,334$ million compared with $\$ 2,211$ million for the non-bailed-out firms. Leverage, the total liabilities divided by total assets, is high in both subsamples, which, given we are dealing with the banking sector, is not surprising; financial institutions own few fixed assets that can be used as collateral. Indeed, Collateral, the ratio of Plant, Property, and Equipment to total assets, does not exceed five percent and is usually much smaller. Book-to-market is defined as the natural log of the ratio of book value of equity to market value of equity, measured at the beginning of the current fiscal year. On average, bailed-out firms have lower (more negative) book-to-market ratios than non-bailed-out firms do, although in the median values the difference is less pronounced. The average market-adjusted daily returns over the first six months of 2008 (Avgmktadjret) confirm that the representative bailed-out firm was perceived as having more bad news than the representative non-bailed-out firm; nevertheless, in the same period the mean volatility of the daily returns (Stdret) does not vary significantly between the two groups. We also consider ownership concentration, (\%Closely held, that is, the percentage of shares held by insiders) and institutional ownership (\%Inst. Ownership, that is, the percentage of shares owned by institutions). Bailed-out firms tend to be less closely held, but have greater institutional ownership than those firms in the non-bailout sample. Institutional holdings data is taken from Thomson Reuters and insider data is taken from Thomson ONE Banker.

\section{Equity ownership held by members of Congress}

In our sample of 555 firms, 120 financial institutions have one or more politicians among their investors. At the beginning of 2008, 69 financial institutions had at least one senator and 97 firms had at least one representative among their equity owners. The summed equity owned by

\footnotetext{
${ }^{20}$ Because we include firms from both the banking and insurance industries, we do not report industry-specific statistics, such as regulatory (Tier I) capital for banks. In a recent report, the special inspector general for TARP (SigTarp) describes regulatory capital as an important ingredient in approval decisions for admitting banks to the CPP (SigTarp 2009a). In its quarterly report to Congress in October 2009, however, SigTarp (2009b) notes "The audit also finds that Treasury and other regulators' descriptions of the financial conditions of the first nine institutions as 'healthy' were inconsistent with the private beliefs of decision makers at Treasury and the Federal Reserve, and later proved to be inaccurate. . . . Treasury lost credibility when lending at those institutions did not in fact increase and when subsequent events - the further assistance needed by Citigroup and Bank of America being the most significant examples-demonstrated that at least some of those institutions were not in fact healthy" (p. 8). This would suggest that the decision to approve support is not a mechanical function of regulatory capital and other indicators of financial health.
} 
members of Congress in the average firm in our sample ranges between $\$ 69,000$ and $\$ 182,000 .{ }^{21}$ To illustrate the economic significance of the equity ownership held by members of Congress, consider the following. In 2008, the collective ownership held by senators in our sample was between $\$ 15.1$ and \$26.3 million, whereas the total investment held by members of the House was between $\$ 23.3$ and \$74.5 million. While politicians owned only a small fraction of shares in these financial institutions, these firms are meaningfully represented in the investment portfolios of politicians. On average, the investment in the financial sector constitutes about 6 percent of the net wealth (total assets minus liabilities) of both senators and representatives provided that they hold equity in financial institutions. Over $30 \%$ of the politicians invested in the financial institutions in our sample during 2008; the proportion of investors is higher in the Senate than in the House.

We obtain our data about Congress members' equity ownership from the Center for Responsive Politics. ${ }^{22}$ According to the Ethics in Government Act of 1978, members of Congress (and Executive Branch officials) are required to file annual reports disclosing their personal finances. Congressional ethics committees enforce and oversee compliance with this requirement. Financial Disclosure Report forms record income, assets and related transactions, liabilities, and sundry other items and must be filed annually by May 15 for the prior calendar year. ${ }^{23}$ The Center for Responsive Politics collects these reports from the Senate Office of Public Records and the Office of the Clerk of the House. ${ }^{24}$

Congress members must report all assets that are held for investment or for the production of income and worth more than $\$ 1,000$ at year-end. This includes securities, real estate, businesses owned, bank accounts, and loans owed to the filer. The Center screens each of these assets, and we populate our database with reported equity investments in publicly listed financial institutions (SIC 60-69) only. Assets held in any self-directed account or fund must be listed individually, along with

\footnotetext{
${ }^{21}$ As we explain below, in our regressions we take the midpoints of a range used by Congress members to report their assets.

${ }^{22}$ We use the web query on www.opensecrets.org to retrieve the data. The classification of reported assets in the disclosure reports is not always straightforward. We rely on the CRP classification of assets as stock and verify this with the original disclosure reports if their classification is missing or unclear.

${ }^{23}$ These include contributions made in lieu of honoraria, gifts received, non-governmental positions held, travel that was paid for, and information referring to the member's spouse and dependent children.

${ }^{24}$ The reports are scanned into digital images and made available on the Center's website.
} 
their value and the type and amount of income they produced. Assets producing more than $\$ 200$ in annual income must be listed, regardless of their value at year-end. Filers often report the value of each of their assets within one of several ranges. We use the midpoint of the range as our estimate of that asset's value. When a politician mentions owning an asset but reports its value as "N/A." we view this as a below-disclosure-threshold holding and count the asset as an investment but assign it a zero dollar amount. ${ }^{25}$ We collect data on the equity ownership of Congress members at the start of 2008 (using the closing balance of December 31, 2007 in their 2008 filing).

\section{Voting in Congress on proposals to bail out the financial sector}

We conduct two tests on the association between government intervention and equity ownership held by politicians. In this section, we examine Congress members’ voting behavior on key legislative proposals regarding the bailout of the financial sector. In the next section, we focus on three congressional committees under whose jurisdiction many of the measures to provide stability to the financial sector were taken.

\subsection{Main analysis}

On September 20, 2008, Secretary Paulson released his three-page "Legislative Proposal for Treasury Authority to Purchase Mortgage Related Assets.” Two days later, Senator Dodd advanced a more detailed draft, and on September 29, after many negotiations, the House voted on a bill (H.R. 3997), now 110 pages long, that combined this draft with Mr. Paulson's original. The House rejected the bill, with 205 in favor and 228 against. On October 1, 2008, however, the Senate approved H.R. 1424, an amended version of the bill that included the final TARP language, with 74 in favor and 25 against. On October 3, the House voted to concur with the Senate on H.R. 1424 and accepted the bill 263 to 171. That day, the President signed the bill into Public Law 110-343 (SigTarp 2009b).

We examine whether the equity ownership held by members of Congress is associated with their votes on the three occasions described above (i.e., the House vote on H.R. 3997, the Senate vote on H.R. 1424, and the House vote on H.R. 1424). We predict that members who have ownership in that sector are more likely to vote in favor of each of the proposals. With respect to the two House

\footnotetext{
${ }^{25}$ This matters in analyses where we use indicator variables that denote investor status (which will take the value of 1 for assets valued as N/A) and variables that use the dollar amount of investments (which will be zero).
} 
votes, we expect the first vote to best reflect individual members' preferences because at the second vote the leadership of both parties put considerable pressure on the membership to approve the bailout. $^{26}$

We estimate logit regressions of the likelihood that a given politician will vote in favor of each of the three legislative proposals. The dependent variable takes the value of one if a politician votes for the proposal (Aye) and zero otherwise (No). In our regressions, we include as our variables of interest the logarithm of the politician's total investment in our sample firms (Equity ownership in financial sector), the logarithm of the total PAC donations made by these firms to that politician (PAC donations by financial sector), and the Importance of the financial sector to the politician's home state (measured as the total number of employees in the financial activities sector (seasonally adjusted) divided by the total number of employees in all sectors (seasonally adjusted)). Together these variables capture the economic incentives of politicians in congressional voting. Following Mian et al. (2010b), we view PAC donations by financial sector as a proxy variable for politicians' incentives to respond to the special interests of the financial service industry and Importance of financial sector as a proxy for the incentives for responding to constituent interests. Campaign donations are traditionally seen as a measure of special interest (Kroszner and Stratman 1998; Milyo, Primo and Groseclose 2000). We follow Cooper et al. (2010) and use a longer-term measure of donations by considering the financial sector's total PAC spending between 2003-2008. ${ }^{27}$ When a larger percentage of the electorate is working in the financial sector, their interests represent an increasing number of (potential) voters within the politician's electorate. Equity ownership in financial sector measures a politician's economic incentives that derive from personal wealth interests. In some specifications, we replace the total investment in our sample firms with a variable that captures the Expected losses due to ownership in financial sector. We compute this variable by multiplying the number of shares a politician holds in our sample firms at the beginning of 2008 by each of these shares' change in stock

\footnotetext{
${ }^{26}$ http://www.nytimes.com/2008/10/02/business/02bailout.html

${ }^{27}$ If firms employ a long-term strategy of political donations (which would be consistent with Kroszner and Stratman (1998)), it is more relevant to compare the effects of personal wealth incentives with a long term measure of contributions. Following Cooper et al. (2010), we sum the contributions in the election cycles 20032004, 2005-2006, 2007-2008. Results on the variables of interest remain unchanged when we use only campaign donations during the 2007-2008 election cycle.
} 
price on September 29. We develop this variable because we would like to include a measure of the expected losses in the event the bailout bill does not pass; the losses realized due to the drop in stock prices after the House failed to pass the initial bailout proposal is a reasonable proxy for the same. To determine whether it is indeed the politician's wealth interest in the financial sector as opposed to his or her investment in non-financial firms, we contrast our proxies for personal wealth interest in the financial sector with Equity ownership in S\&P 500 firms (i.e., the log of the politician's total investment in S\&P 500 firms excluding financial sector firms) and Expected losses due to ownership in S\&P 500 firms (i.e., the number of shares in non-financial S\&P 500 firms at the beginning of 2008 multiplied by each share's change in stock price on September 29). ${ }^{28}$

We include controls for party affiliation (an indicator variable that takes the value of one if the politician is a Republican), Election margin (the margin of victory over the closest competitor in the most recent congressional election), and the politician's seniority in Congress (see, e.g., Kau et al. 1982). We also control for Ideology score, which is defined as the first dimension of the DWnominate representative ideology score, and increases in the degree of conservatism. The DWnominate measure is a widely used in the political science literature (Poole and Rosenthal 2007). To check for robustness, in some specifications we use (a politician's) home-state fixed effects instead of our measure of the financial sector's importance to that state. Table 2, Panel A presents the descriptive statistics on these variables, and Panel B presents our estimation results. We find that equity ownership is associated at the 1 percent level with members of the House voting in favor of H.R. 3997 on September 29 and at the 5 percent level with voting in favor of H.R. 1424 on October 3. This finding is not sensitive to including home-state fixed effects (see Column 2). In contrast, we find no association between senators' equity ownership and their vote on H.R. 1424 on October 1 (see Column 4). This finding also leads us to consider the average predicted probability of, on the one hand, politicians who own equity in the financial sector voting for the bailout proposals and, on the other, politicians who don't own equity in the financial sector voting for the proposal. In the initial

\footnotetext{
${ }^{28}$ We use the end of year holding of stocks to compute the expected losses instead of the holdings on September 28, (i.e., on the eve of the initial vote) to avoid having to rely on incomplete data about a politician's stock transactions during 2008 (see also, Section 7 below). Our results do not change materially, however, if we use transaction-adjusted data to compute expected losses.
} 
House vote, the predicted probability of voting for the bailout proposals is 42 percent for noninvestors and 60 percent for equity owners; in the final vote, the predicted probabilities are 56 and 72 percent, respectively. ${ }^{29}$

We obtain very similar results when we use our measure of Expected losses due to ownership in the financial sector. Again, we find a significant association between ownership in the financial sector and voting in favor of both the initial and final House bailout proposals (see Columns 3 and 7, respectively). In the Senate, once more, ownership does not materially affect the vote on H.R. 1424 (see Column 5).

In contrast, what does affect voting behavior is a representative's ownership in the financial sector; we find no significant association between the (expected losses due to) equity ownership in the S\&P500 firms (excluding the financial sector) and any of the three roll call votes.

Campaign donations also do not affect the Senate vote, whether we measure these donations as a total dollar amount or (unreported) as an indicator variable. On the other hand, campaign donations are significant at the 10 percent level or better in explaining the House's initial vote as well as in the final roll call. ${ }^{30}$

We separately examine a sample of the 228 representatives who voted against the H.R. 3997 on Sept. 29, to understand their incentives to switch votes in the second roll call on Oct. 3 (detailed in Columns 8 and 9). Neither proxy for a politician's personal wealth interest in the financial sector (i.e., Equity ownership in financial sector or Expected losses due to ownership in financial sector) is significantly associated with the final vote. PAC donations by the financial sector, on the other hand, are strongly positively associated with this vote. Thus, we conclude that PAC donations, but not equity ownership predict which politicians change their vote from "no" to "aye" in the second roll call.

Our control variables show that House Republicans are somewhat more likely to vote against the initial bailout proposal than House Democrats are. Consistent with reports that the passage of H.R. 1424 resulted from a bipartisan coalition of senators, party affiliation does not explain the vote in the

\footnotetext{
${ }^{29}$ We use the estimation results of a specification with an indicator variable equal to one if the politician invests in our sample firms and zero otherwise for these computations.

${ }^{30}$ The results on the effect of campaign donations on the initial House vote are sensitive to how donations are measured. If we use the donations in the most recent election cycle only (2007-2008) instead of our longer-term measure, PAC donations no longer obtain significance at conventional levels.
} 
Senate. ${ }^{31}$ Care needs to be exercised, however, when interpreting these control variables. Republican, Ideology, and Election margin are all highly correlated. ${ }^{32}$ Ideology score matters particularly in the final House vote, wherein more conservative members are less like to vote in favor of the bailout proposal and are less likely to change their vote. A Congress member's seniority increases his or her likeliness to vote in favor of the bailout proposals. Election margin does not attain significance in any of the regressions; however, this appears to result from its correlation with the Republican indicator variable.

In unreported analyses, we include an indicator variable that takes the value of one if the politician is a member of one of the three financial-sector-related congressional committees (i.e., the Senate Banking, Housing and Urban Affairs committee, Finance committee, and the House Financial Services committee), and zero otherwise. This variable is not significantly associated with the vote on the bailout proposals and its inclusion does not affect inferences on our variables of interest.

In addition, we replace a given politician's total investment in our sample firms with an indicator variable equal to one if the politician invests in these firms and zero otherwise. In contrast to total equity investment, this indicator variable captures a politician's exposure to the financial sector without inadvertently also capturing that politician's total wealth. Likewise, we replace the expected losses due to ownership in the financial sector with an indicator variable equal to one if the politician has positive expected losses and zero otherwise. Using indicator variables to capture personal wealth incentives does not materially affect our results. ${ }^{33}$

\subsection{Exposure of a politician's wealth to the financial sector and voting on bailout proposals}

We provide a different perspective on the role of personal wealth incentives by examining whether politicians whose wealth prior to the crisis was sensitive to changes in the stock price performance of the financial sector voted differently than investors whose wealth was relatively

\footnotetext{
${ }^{31}$ http://www.nytimes.com/2008/10/02/business/02bailout.html

${ }^{32}$ Ideology score is highly correlated (corr. $=0.94$ ) with Republican, the indicator variable for the Republican party. Similarly, republican politicians tended to have lower margins of victory in the most recent election. We decided to include all variables in our regression in recognition of their central role in the political economy literature.

${ }^{33}$ For consistency, we replace at the same time the total PAC donations made by our sample firms with an indicator variable equal to one if the politician receives PAC donations from any firm in our sample and zero otherwise. Detailed results are available from the authors upon request.
} 
impervious to price volatility in the financial sector in the same period. Our intuition is as follows: if politicians vote according to their personal financial interests, then those whose wealth was more likely to be exposed to the adverse consequences of the financial crisis had stronger incentives to vote in favor of government support for the sector (and thereby perhaps recover some of their losses) than politicians whose assets were likely to be relatively unaffected by the crisis. Using the annual personal financial disclosures 2004-2007, we collect the net wealth of all members of congress. We then pool politicians based on whether they voted in favor of or against H.R. 3997 (in the House) and H.R. 1424 (in the Senate), thereby forming four separate groups. For each of the four groups, we estimate a pooled cross-section time series regression model of the annual dollar amount change in net wealth deflated by assets onto the percentage change in the S\&P North American Financial Services Sector Index. ${ }^{34}$ The coefficient estimates taken from these regressions can be interpreted as a politician’s Sensitivity of wealth to the financial sector (as measured prior to the voting).

Table 2, Panel C reports the results of these regressions. The only group of politicians with a significantly positive Sensitivity of wealth is those House representatives who voted in favor of the initial bailout proposal. To obtain a sense of the economic significance of these politicians' wealthsensitivity, we compute the dollar change in net wealth that would result from a 10 percent increase in the financial sector index. For this exercise, we use the median (mean) total assets of House representatives who voted in favor of the proposal. When we use the median total assets, the dollar wealth sensitivity to a 10 percent increase in the index is approximately $\$ 50,000$; the estimate is much higher when we use the mean total assets and approaches $\$ 300,000$. The change in the S\&P Financial Services index on the day the initial bailout proposal was rejected by the House (i.e., on Sept. 29) was -14.4 percent. The annual change in the index in 2008 was -51.96 percent. Together, these results suggest that the impact of the financial crisis on politician's wealth was potentially substantial (at least for those politicians who voted in favor of the initial proposal in the House).

Observe that the estimated wealth-sensitivity of those Senators who opposed H.R. 1424, is almost of the same magnitude as the wealth-sensitivity of House members who favored the initial

\footnotetext{
${ }^{34}$ We deflate changes in net wealth by total assets to avoid computing percentages over negative values of net wealth (which occur with some frequency in the sample).
} 
proposal. However, possibly owing to a lack of power (only 25 Senators voted against the bill), the estimated wealth sensitivity is not significant in this group. We therefore conclude with some caution that this finding reaffirms the evidence presented in Table 2, Panel B, which suggests that personal wealth interests appear to have played a smaller role in the Senate vote.

\subsection{Constituent or personal financial interests: investments in home-state financial institutions}

In the following regressions, we split a politician's equity ownership in the financial sector into two new variables: an indicator variable that takes the value of one if the politician is an Investor in home-state financial institutions and zero otherwise and an indicator variable that takes the value of one if the politician is an Investor in out-of-state financial institutions and zero otherwise. Home-state financial institutions are institutions whose headquarters are located in the politician's home state. In addition, we compute a variable that captures the number of home-state (out-of-state) financial institutions owned by the politician (i.e., Number of financial institutions in (outside of) home state owned). We do so to more precisely capture the economic incentives that derive from personal wealth interests. It is possible that the correlation we observe between a politician's vote and their equity ownership in the financial sector is not due to economic incentives deriving from the politician's portfolio investments but instead from their acting in support of their local constituencies. If members of Congress become equity holders in local financial institutions to display their community roots and vote for a bailout that benefits their local banks, then we expect to find an association between the Investor in home-state financial institutions variable and voting in favor of the bailout. We use indicator variables (instead of the dollar amount of the equity holding) to capture the idea that for politicians to show their support for their constituency what matters is not so much the dollar amount of their investments but that they invest at all. ${ }^{35}$ To further parse out personal wealth incentives from constituent interests, we include the Number of home-state financial institutions owned variable, which reflects the "breadth" of the politician's support for their local community. Our logic is that support for a local community is more forcefully expressed by taking ownership in many local financial institutions (instead of just a few).

\footnotetext{
${ }^{35}$ Nevertheless, when we use dollar amounts of equity ownership in home state and out-of-state financial sector, we continue to find that out-of-state equity ownership is associated with the vote on H.R. 3997, whereas home state equity holdings are not associated with the same.
} 
While home-state equity ownership could arguably represent constituent interests as well as personal wealth interests, constituent interests cannot explain a positive association between voting for the bailout and the Investor in out-of-state financial institutions variable. Indeed, ownership in outof-state firms by definition cannot help politicians to signal to voters that they are committed to supporting the local economy. It might be the case that special interests (i.e., campaign donations from banks) explain why politicians invest in out-of-state financial institutions. If this is the case, we expect politicians to invest in many banks instead of concentrating their investments so as to forge relations with many potential donors. Thus, we include the Number of out-of-state financial institutions owned to obtain a cleaner measure of Investor in out-of-home state financial institutions that reflects personal wealth considerations.

Our results in Table 2, Panel D show that in the House vote the Investor in out-of-state financial institutions variable is significantly associated with voting in favor of the bailout proposals. None of the other ownership variables obtains significance at conventional levels, which is consistent with personal portfolio considerations explaining the two House votes. Indeed, there is little evidence to suggest that a politician's support for the bailout is associated with their investments in home-state financial institutions. ${ }^{36}$

5.4 Ideology vs. economic incentives: Relative roles of constituent, special, and personal financial interests

Mian et al. (2010b) find that a politician’s ideological position can be a commitment device to resist pressures from constituents and special interests to vote for government intervention in the economy. More conservative politicians, in particular, seem less responsive to these pressures, but whether such politicians are also less responsive to incentives arising from personal wealth interests remains an open question. Alternatively, the voting decision can be seen as the outcome of a cost/benefit tradeoff, in which the cost of voting in the interest of a politician's personal wealth is weighted against the cost of going against one’s convictions. Voting in favor of intervention, then, is more costly for conservative politicians. We follow Mian et al. (2010b) and use Ideology score to

\footnotetext{
${ }^{36}$ The results for the Senate are unchanged when splitting the equity ownership in the financial sector into home state and out-of-state investments. None of the equity ownership variables are significant.
} 
measure the degree of conservatism. ${ }^{37}$ We drop the Republican indicator variable from our specification to avoid multicollinearity issues arising from the high correlation between party affiliation and ideology.

To test whether a politician's ideological position can help them to commit against succumbing to pressures from constituent, special, and personal financial interests, we interact our proxies for each of these interests with Ideology score. The interaction term also captures that the costs of voting for government intervention depend on the strength of a politician's ideological position. As interaction effects in logit models are known to be difficult to interpret (Ai and Norton 2003), we present the evidence in Table 2, Panel E in the form of marginal effects. We compute the marginal effect of each proxy variable representing constituent, special, and personal financial interests at three values of Ideology score. We use the sample minimum (i.e., most liberal), median, and maximum (i.e., most conservative) values. The findings suggest that a politician's ideology does prevent them to some extent from voting in accordance with their personal financial interests. The marginal effect of Equity ownership in financial sector on both votes is significantly positive for all but the most conservative politicians (for whom the marginal effect is no longer significant). Similarly, but more weakly, ideology mitigates the sensitivity of a politician's vote to pressure from special interests (i.e., long-term PAC donations). Again, a politician’s donations from the financial sector no longer explain the vote for the most conservative representatives. Ideology changes the sign of the relation with respect to the sensitivity to constituent interests, at least in the initial vote. The marginal effect of the importance of the financial sector on the likelihood to vote in favor of the bailout proposal changes from positive to negative as we consider more conservative politicians and is significant at the 10 percent level for those who hold the most conservative views. ${ }^{38}$

\subsection{Seat safety and personal financial interests}

The costs of voting in the interest of preserving or recovering personal financial wealth and against the interest of voters may depend on the safety of the seat. Politicians who enjoyed a

\footnotetext{
${ }^{37}$ We emphasize the results of the House vote as we have already documented in Panel B that ideology does not explain the Senate vote.

${ }^{38}$ Note, however, that a direct comparison between our study and Mian et al. is not feasible since key variables were measured differently.
} 
comfortable margin of victory in the most recent election might be less concerned about losing their seat when their vote in Congress goes against constituent interests than those who won the election with the narrowest of margins. We explore this possibility by augmenting our logit regressions with an interaction of Equity ownership in financial sector with Election margin. We evaluate how ownership in the financial sector is associated with each of the House votes by computing marginal effects for different victory margins. Unreported results show that regardless of the magnitude of the election margin, personal financial wealth interests increase the probability of a politician voting in favor of both H.R. 3997 and H.R. 1424.

\section{Equity ownership of committee members and government support decisions}

We now shift our focus to the implementation of TARP policy after Congress accepted EESA. Given our sample of financial institutions, we ask whether the equity ownership held by politicians, especially by those with a seat on financial sector-related committees, in these firms is associated with the firms' likelihood of receiving government support. Note that the level of analysis has changed from politicians to firms. We control for special and constituent interests which may affect the politician's decision and for different mechanisms through which the fates of firms and politicians are tied together, such as via politically connected boards.

\subsection{Summary statistics on equity ownership, donations, and board membership}

Table 3 partitions the sample into those firms that were approved for a bailout and those that were not. The table also provides univariate tests of the differences between the two subsamples for equity ownership, campaign donations, lobby expenditures, and the presence of (former) politicians on the board of directors. We find that bailed-out firms donated more to federal election campaigns. In the 2003-2008 election cycle, bailed-out firms averaged \$65,990 in PAC donations, whereas nonbailed-out firms averaged $\$ 19,130$. Bailed-out firms, on average, also fund the campaigns of more Federal election candidates than do their counterparts. The two samples' degree of equity ownership and number of politicians among their investors are also substantially different. We distinguish between the ownership of members seated on one of the three committees related to the financial sector (i.e., the Senate Banking, Housing, and Urban Affairs committee, the Senate Finance committee, and the House Financial Services committee) and the ownership of those who are not. We 
further divide the committee members' ownership into investments held by powerful politicians (i.e., those who chair a (sub)committee or are its ranking members) and investments held by non-powerful politicians. The mean ownership held by non-committee members in non-bailed-out firms is $\$ 14,360$, whereas in the bailed-out firms the average ownership is $\$ 155,200$. Furthermore, the investment of non-powerful committee members is very similar in bailout and non-bailout firms (approximately $\$ 6750$ and $\$ 6620$ on average). Powerful politicians, on the other hand, hold much larger stakes in the bailed-out financial institutions than in the non-bailed-out institutions. These members own, on average, less than $\$ 500$ in the non-bailed out sample firms, but over $\$ 55,000$ in the institutions that received government support. In addition, Table 3 presents details about the number of committee and non-committee members who are investors in these firms. We find that the average number of investors in each firm is low. Given that our sample comprises 555 firms whereas our three congressional committees comprise 115 politicians, ${ }^{39}$ this finding is not surprising; it is unlikely that the investment portfolios of these politicians would contain every publicly listed financial firm. Note that the median values of ownership and donations are zero in both samples; for this reason, we also provide the proportion of firms that report positive ownership and donations.

Bailed-out firms more often have board members who are affiliated with the Republican Party than non-bailed-out firms. Finally, we note that both samples' average lobby expenses are considerable. These averages, however, are driven by some very large observations. ${ }^{40}$

\subsection{Equity ownership of committee members}

In this section, we consider the likelihood of a particular firm being bailed out, the amount of bailout received, and the timing of that receipt in relation to the equity ownership in financial sector firms held by members of the Banking, Housing, and Urban Affairs, and Finance committees in the Senate as well as by members of the Financial Services committee in the House of Representatives. In addition, we discuss how financial sector campaign contributions to the same Congress members and the presence of a politically-connected board affects the bailout decisions. In these analyses, Equity

\footnotetext{
${ }^{39}$ In the $110^{\text {th }}$ Congress, the committee membership was as follows: Senate Banking, Housing and Urban Affairs (22), Senate Finance (21), House Financial Services (76). Three members joined both the Senate Banking and Finance committees and one member switched from the Banking to the Finance committee.

${ }^{40}$ For example, AIG (in our bailed-out sample) reports combined lobby expenditures of $\$ 21,069,000$ in the 2007-2008 election cycle, and MetLife (in our non-bailed-out sample) reports \$10,270,000 for the same period.
} 
ownership by members of committee $j$ is defined as the log of the sum of the equity ownership across all members in committee $j$ in firm $i$, and PAC donations to members of committee $j$ is defined as the $\log$ of the sum of the donations to all members of committee $j$ by firm $i$ in the election cycles 2003$2008{ }^{41}$ Similarly, Number of investors among members of committee $j$ (Number of PAC recipients) is defined as the log of the number of committee members with positive investments in firm $i$ (i.e., positive PAC donations from firm i). Dem (Rep) Board is defined as the number of board members who serve or have served in any elected position on behalf of the Democratic (Republican) Party. Likelihood of receiving bailout. We estimate cross-sectional logit regressions that model the likelihood of a firm receiving government support under TARP as a function of a set of control variables that proxy for the firm's financial condition and its importance to the economy ${ }^{42}$ (Faccio et al. 2006). We include controls for ownership concentration (\%Closely held) and institutional ownership (\%Inst. ownership) for two reasons. First, prior research has documented that the corporate governance quality of financial institutions matters in bailout decisions (Duchin and Sosyura 2009) as well as in investor portfolio decisions (Denis and McConnell 2003). Prior research also documents that both ownership variables affect corporate governance quality (Shleifer and Vishny 1997; Denis and McConnell 2003). In addition, these variables capture how widespread the damage might be should a bank collapse. If ownership is widespread, then a larger proportion of voters is likely to be affected by default. Similarly, if financial institutions hold a larger share in a bankrupt bank then their own health will also be compromised, which in turn might likewise affect voters. We further include measures of the presence of a politician on a firm's board, a firm's PAC donation amount, and our variable of interest, namely, the dollar amount of equity ownership held by committee members. ${ }^{43}$ In some specifications, we also use the log of the per-firm number of investors in each committee because it may be the case that what matters is not the dollar amount of "political ownership" but

\footnotetext{
${ }^{41}$ Comparable to our approach in the voting regressions, we use a longer-term measure of campaign donations. All results are robust, however, to a short-term measure of campaign donations that consider only spending in the 2007-2008 cycle.

${ }^{42}$ We specifically analyze the role of constituent interests on committee decisions below. However, the size of the financial institutions can be considered as a proxy for its importance to the economy and, perhaps, how much voters are interested in its survival.

${ }^{43}$ Since the TARP application process is unobservable, we cannot use a self-selection model in which we first predict which firms apply for TARP funding and then explain the bailout decision by our variables of interest.
} 
simply the number of members who have taken an interest in a given firm. For similar reasons, we report the log of the per-firm number of PAC recipients in each committee because, likewise, what matters in politician-firm relations might be the number of candidates supported, not the dollar amount of PAC donations. We also include an indicator variable that takes the value of one for life insurance companies, and zero otherwise. The results are tabulated in Table 4, Panel A. For brevity's sake, except in Panel A, we report only the coefficients on those variables that capture relations between politicians and firms. Nevertheless, all subsequent regressions include the same set of control variables.

We include in all regressions the per-firm total PAC donations or the total number of PAC recipients (including donations to/recipients among committee members) and the total ownership held by non-committee members (or total investors among non-committee members). We do so in an effort to control for each firm's general propensity to donate to politicians' campaigns as well as for each firm's overall political ownership. We find that campaign donations and ownership are highly correlated. In addition, donations to committee members are highly correlated with ownership by those committee members. To avoid collinearity issues, we follow Cooper et al. (2010) and orthogonalize total PAC donations by the total ownership of committee members and include the residuals (i.e., that fraction of PAC donations that is unrelated to ownership held by committee members) in our regressions. We likewise orthogonalize the number of PAC recipients by the total number of investors among committee members.

We find that the likelihood of a firm receiving a bailout is positively associated with the equity ownership in that firm held by members of the Senate Finance committee and of the House Financial Services. ${ }^{44}$ We find very similar results when we use the per-firm number of committeemember investors as our measure of ownership (see Table 4, Panel A, Columns 5-8). The variables that capture the propensity of firms to engage in campaign financing are not generally significant, although there is some evidence that the number of PAC recipients to which a firm contributes

\footnotetext{
${ }^{44}$ All inferences are based on robust standard errors.
} 
increases its likelihood of receiving support. Rep board is significantly positively associated with the probability that a firm receives government support. ${ }^{45}$

Bailout amount. In Table 4, Panel B (Columns 1-4), we present Tobit regressions ${ }^{46}$ using the bailout amount as our dependent variable. ${ }^{47}$ For the Senate Finance committee and the House Financial Services committee, we find a positive association between the sum of the equity ownership in financial sector firms held by members of these committees and the amount of bailout committed. The number of investors among committee members presents much the same picture (untabulated), with the exception that the number of investors in the Senate Finance committee is not associated with the bailout amount. Thus, we find that the larger a firm's amount of equity ownership held by committee members or the greater the number of investors among these members, the more bailout funds the firm stands to receive. Collectively, our results for the bailout amount mirror those for our logit regressions of a firm's likelihood of being bailed out. In fact, when both sets of results are taken together, the evidence consistently shows that equity ownership in a firm held by committee members is positively associated with that firm receiving government support.

A firm's total PAC donations (including those made to committee members) do not, generally, affect the amount of bailout committed and neither does the total non-committee ownership in that firm. We do find some support for a positive association between the number of politicians receiving PAC donations and the bailout amount (untabulated). The number of politicians' campaigns a firm supports appears to have a stronger effect than the amount of money the firm contributed per se.

Timing of the bailout. In the following regressions, we consider the timing of the bailout. We estimate a Cox proportional hazard model with the hazard rate as our dependent variable. The hazard rate is defined as the probability of a firm experiencing the event (i.e., receiving a bailout) at time $t$, given that the firm has survived until time $t$. Observations had either experienced the event (i.e., been bailed

\footnotetext{
${ }^{45}$ Note that Size is a positive and significant control variable in alternative specifications in which we drop \%Closely held and \%Inst. Ownership.

${ }^{46}$ Our use of Tobit regressions is motivated by the fact that the dependent variable takes on the value of zero with positive probability but is a continuous random sample over strictly positive values. Wooldridge (2002, pg. 518) recommends using a corner solution (i.e., Tobit) model for this setting. Intuitively, the idea is that the decision maker (here, the Treasury) solves an optimization problem and for some firms the optimal choice will be the corner solution of allocating zero support to a firm (see also, Leuz, Lins and Warnock (2010)).

${ }^{47}$ Our sample size decreases to 547 because we dropped the firms that were approved for bailout by the Treasury but declined to be bailed out and for which we could not find data on the approved amount from all regressions that use the bailout amount as the dependent variable.
} 
out), in which case we observe a bailout date, or, as of November 6, 2009, they had not (yet) experienced the event. Table 4, Panel B (Columns 5-8) presents the results of these regressions. A positive coefficient implies that increasing the regressor also increases the hazard rate, that is, the likelihood that the firm will experience the event (i.e., receive a bailout). ${ }^{48}$

We find that the equity ownership held by committee members is positively associated with the hazard rate, which implies that politician ownership increases the probability that a firm will be bailed out at an earlier date. The number of investors among committee members also increases the probability of an early bailout, although this is not the case for the Senate Banking, Housing, and Urban Affairs committee (untabulated). We find that both Dem board and Rep board are significantly positively associated with the hazard rate. While having a democratic board of directors did not influence the likelihood of receiving support or the amount approved overall, it did seem to benefit the firm with respect to the timing of the bailout decision. Total PAC donations and the total number of PAC recipients (untabulated) are positively associated with the hazard rate in many regressions.

Constituent interests vs. personal wealth incentives. One possible interpretation of our results is that committee members tend to invest in their home state (e.g., to show support for the banks in their election district). A positive association between bailout decisions and committee members' equity ownership can arise in such a case because both bailout and ownership are reflections of a politician's support for his or her local constituency. Once we control for the presence of members in the committee from the state wherein the financial institution is headquartered, however, the equity ownership held by committee members more precisely captures the incentives deriving from personal wealth. ${ }^{49}$ We examine these scenarios by splitting the equity ownership of committee members into two variables: (1) the ownership of those finance-related committee members from the state wherein firm $i$ is headquartered and (2) the ownership of committee members from another state. We also include in our regressions the percentage of investors among the members seated on the three financerelated committees from the state wherein firm $i$ is headquartered. Our results are presented in Table 4,

\footnotetext{
${ }^{48}$ Note that we report coefficients and not hazard rates in this table and all subsequent survival analyses.

${ }^{49}$ Similar to our reasoning before, we argue that ownership in financial institutions in a politician's home state is unlikely to be fully explained by members demonstrating their support for local firms. Given the preferences of investors for firms they are familiar with or which are located in close geographical proximity, it is reasonable to assume that ownership in home state firms also at least partially is driven by portfolio considerations.
} 
Panel C. We find that ownership by committee members from the state wherein the firm is headquartered is not statistically related to the probability of that firm receiving a bailout or the timing of the bailout. In contrast, the ownership by out-of-state committee members is significantly associated with receiving government support. We also find that having a higher percentage of committee members from the state wherein the firm is headquartered increases the likelihood that the firm will receive a greater amount of bailout (see Column 4), but does not affect the firm's probability of receiving a bailout in the first place or the timing of the bailout (Columns 2 and 6). We thus conclude that, with the possible exception of determining the amount of bailout, there is little evidence that supporting their local constituency is what motivates politicians' bailout decisions. Personal wealth considerations, on the other hand, seem to play a role in all such decisions.

\subsection{Powerful politicians: Chairpersons and ranking members}

In this section, we provide evidence regarding the effect that the equity ownership of powerful members on the Senate Banking, Housing, and Urban Affairs, the Senate Finance, and the House Financial Services committees has on government intervention decisions. Specifically, we consider a politician to be powerful if they chair or are the ranking member of a committee or one of its subcommittees. In the $110^{\text {th }}$ Congress, chairpersons are always Democrats, whereas ranking members are Republicans. Each committee has five subcommittees. As before, we document the effect of equity ownership on the amount of bailout committed and the timing thereof. ${ }^{50}$ Ownership: powerful members (non-powerful members) is defined as the sum of the equity ownership in firm $i$ held by powerful (non-powerful) committee members in committee $j$. PAC donations: powerful members (non-powerful members) is defined as the total campaign contributions made by firm $i$ to all powerful (all non-powerful) committee members in committee $j$. While this analysis is motivated in part by prior literature that underscores powerful members' pivotal role in the daily business of committees, we also use the distinction between the investments of powerful and non-powerful members to address two potential alternative explanations for our findings. First, committee members might be more knowledgeable about the sector they oversee than other politicians and they might use this

\footnotetext{
${ }^{50}$ For brevity's sake, we do not report details for logit regressions of the likelihood of a firm receiving government support. The results are very similar to those based on the bailout amount and generally somewhat stronger.
} 
knowledge to invest in banks that are financially healthier and, because of their financial health, more likely to receive support. Second, committee members might follow a value-weighted investment strategy; that is, if bigger and better performing banks are more likely to be bailed out and if size and financial condition are not fully captured by our set of controls, then we would find a positive association between government support decisions and committee member investments. A priori, we have little reason to believe that either the knowledge or investment strategy of powerful members will differ from those of non-powerful members. Therefore, should we find an association for one of these groups of politicians, but not the other, then these alternative scenarios will lose their appeal.

Bailout amount. We focus our discussion on the regressions in which we use as our independent variables the dollar amount of equity ownership (see Table 5, Columns 1-4). We also conduct (but do not tabulate the details of) all regressions using the number of investors as an alternative proxy. In all regressions, we continue to control for the overall PAC donations and non-committee ownership. We orthogonalize the total PAC donations using the residuals of a regression of PAC donations onto the committee members' combined investments.

The summed equity ownership held by the powerful members of all three committees is positively and significantly associated with the amount of bailout committed. Similarly, the number of powerful investors in all but the Senate Finance committee is positively associated with the bailout amount (untabulated). Note that since the variables that capture ownership held by non-powerful committee members are never significant, it is the ownership held by the committee leaders (i.e., chairs and ranking members) that matters in decisions regarding the amounts of government support. Timing of the bailout. Table 5, Columns 5-8 presents the evidence on the timing of the bailout. We find that the equity ownership of powerful members in all three committees is positively and significantly associated with the hazard rate. The investments of non-powerful members on the House Financial Services committee and on the Senate Finance committee also positively affect the likelihood of a firm receiving an earlier bailout. The picture that emerges regarding the number of investors among powerful politicians (untabulated), is somewhat different. The Ownership combined congressional committees is significant for powerful members only and this result appears driven by the number of investors among the powerful members of the Senate Banking committee. In the Senate 
Finance (and House Financial Services) committee, only the number of non-powerful investors is (marginally) significantly associated with the hazard rate. The different findings between proxies based on the dollar amount of investment and the number of investors imply that what matters in case of non-powerful members is the number of politicians involved, while for powerful members it is the dollar amount at stake.

Taken together, our results show that the equity ownership held by powerful members in the Senate Banking, Housing and Urban Affairs, the Senate Finance, and the House Financial Services committees is positively associated with the amount of bailout committed as well as with the timing of that bailout. Since we find powerful investors to differ from non-powerful investors, alternative explanations for our findings based on knowledge advantages or investment strategies (i.e., favoring investing in larger firms) are unlikely to be valid. In addition, we find some evidence that the ownership held by non-powerful members in the House Financial Services and the Senate Finance committees also increases the hazard rate (i.e., the likelihood of a firm receiving an earlier bailout).

\subsection{PAC donations to (powerful) committee members}

We contrast our findings for committee members' equity ownership in financial institutions with those for financial institutions' campaign donations to committee members. Our empirical strategy mirrors that of the analyses we reported above. We split the total PAC donations into those made to committee members and those made to non-committee members. We control for the total ownership held by all Congress members and the presence of politically connected boards, as well as our usual set of control variables. In subsequent regressions, we further split the PAC donations made to committee members into those made to powerful members and those made to non-powerful members. ${ }^{51}$ In short, we find no evidence that PAC donations made to committee members, be they powerful or not, affects the probability that a firm will receive a bailout, the amount of bailout committed or the likelihood of the firm being bailed out earlier. We do find, however, that the campaign donations made to non-committee members influences the bailout outcomes. In other words, once we account for the overall PAC spending of firms, the specific amount contributed to the campaigns of finance-related committees is not longer significant. This finding is consistent with

\footnotetext{
${ }^{51}$ Details of these regressions are available upon request.
} 
Duchin and Sosyura (2009), who report that PAC donations made to the combined membership of either the House or the Senate are positively associated with the bailout amount. Collectively, we conclude from this evidence that, at the committee level, special interests, as measured by campaign donations, have a role subordinate to personal wealth incentives in explaining bailout decisions.

\section{Robustness checks}

In our voting regressions, we use data on the 2008 opening balance of equity holdings of Congress members. Since the first vote did not take place until September $29^{\text {th }}$, 2008, it is possible that Congress members divested their holdings or bought more stock in financial institutions in the intervening months. If so, then our proxy for equity ownership based on opening balance data would not fully capture the true financial interests of Congress members. As such, we use transactions data from the Financial Disclosure Report to reconstruct the portfolio holdings of each politician on each of the voting days (i.e., September, $29^{\text {th }}$, October $1^{\text {st }}$, and October $3^{\text {rd }}, 2008$ ). We then check the sensitivity of the results reported in Table 2, Panel B to this new equity-ownership variable. We continue to find that equity ownership is significantly associated with the likelihood that a politician will vote in favor of the bailout proposal in the initial House vote (at the 1 percent level or better) and in the final House vote (at the 10 percent level or better), but not in the Senate vote. That said, this transaction data is not very clean. Politicians, for example, do not always report the date on which a purchase or sales occurred. For a significant proportion of the transactions, then, we cannot be sure whether they occurred before or after the roll call on the bailout proposals. In addition, no transaction data is available for those members who did not continue into the $111^{\text {th }}$ Congress. For these reasons, in our main analyses we use the data on the reported beginning balance holdings data.

For descriptive purposes, we document the recorded transactions (i.e., those transactions for which politicians disclosed a date) between September 29 and October 3. Ten members of the House and three Senators engaged in a total of 54 transactions in our sample firms (i.e., 17 sales totaling $\$ 227,500$ and 37 purchases totaling $\$ 226,000$ ) in this period. Most of the transactions (35 out of 54, including 24 buys) took place after the vote in the Senate. These politicians traded more in companies that subsequently received government support (40 transactions including 15 sales) than in those that did not (14 transactions including 2 sales). Five of the trading politicians voted against the initial 
bailout proposal in the House, one of whom changed their votes in the final roll call. All Senators who traded voted in favor of H.R. 1424.

On our sample firms' lobby expenses, we gathered data from 2007 and 2008 to parallel the election cycle. We do not include this variable in our regressions, however, because there is no unambiguous way to attribute lobby expenses to finance-related committees, and our level of analysis is at the committee level. ${ }^{52}$ Nevertheless, when we include in our regressions (the logarithm of) the total lobby expenses in the 2007-2008 election cycle, our conclusions remain unchanged and the variable is not significant. Indeed, only when we include in the regressions no other variables but our controls are lobby expenses marginally significant $(p$-value $=0.12)$.

In our main analyses, we use as our dependent variable (the logarithm of) the bailout amount in dollars. We use this unscaled dependent variable to avoid a mechanical relation between the scalar and the independent variables. However, when we scale the bailout amount by the beginning market value of equity, our results remain largely unchanged, with the exception that we find a positive and significant relation between Dem board and the scaled bailout amount; this finding reaffirms the main regressions’ weaker evidence reported above.

We use market-based indicators of financial distress (e.g., book-to-market) as controls in our analyses. To the extent that the market anticipates bailout decisions, these variables may be subject to endogeneity concerns. When we include accounting-based distress variables (such as the accounting return on assets), however, our results remain unchanged. Indeed, these distress variables are not incrementally significant.

\section{Conclusions}

In a recent speech, President Obama admonished the banking sector for resisting reform of the financial service industry: "I have no intention of letting their lobbyists thwart reforms necessary to protect the American people."53 Our paper's results suggest, however, that forces more subtle than lobbying efforts may serve to align the interests of corporations and politicians and help banks to circumvent reform policies they find too restrictive. While lobbying is indubitably an important

\footnotetext{
${ }^{52}$ See, e.g., Mian et al. (2010a)

53 Remarks made by the President on the economy. December 14, 2009. Available at: http://www.whitehouse.gov/the-press-office/remarks-president-economy-0
} 
means of exerting influence, it is now well recognized that campaign donations (e.g., in the form of PAC contributions) also align the interests of firms and law-makers. Our findings likewise demonstrate that the total amount of PAC donations firms make indeed matters. In addition, the interests of voters can cause politicians to favor government intervention and provide support to financial institutions. What has gone virtually unnoticed thus far is that politicians are also investors and that, as investors, part of their wealth rests with firms whose wellbeing falls under their legislative and regulatory influence. We show that a politician's equity ownership in financial sector firms (with headquarters outside the politicians' home state) can explain their voting behavior on key legislative proposals to bailout the sector after the subprime mortgage crisis of 2007. We also document that congressional equity ownership in a given firm affects both the extent and timing of government support committed to that firm during the bailout of the financial sector. Ultimately, however, we find that when it comes to making and implementing these decisions, equity ownership only matters at the committee level. Note that while all members of Congress could vote on the bailout proposals, only financial-committee members oversee the implementation of TARP. Thus, it is not surprising that the explanatory power of equity ownership varies based on whether we are considering the voting behavior of all Congress members or the oversight of the implementation of TARP by just those members of financial committees. In addition, we show that the ownership held by powerful members in congressional committees with jurisdiction over the financial sector particularly matters.

We cannot fully identify the causal mechanism driving the reported associations between politician equity ownership in firms and government intervention in the economy. Many of the tests we conduct, however, are consistent with the interpretation that the personal wealth incentives deriving from equity ownership are separate and distinct from those deriving from special or constituent interests. Politicians are investors and while their investments may have political motives, the evidence in our paper shows that their political decisions are affected by the ensuing consequences on the politician's personal wealth.

\section{References:}

Aggarwal, R. K., F. Meschke and T. Wang (2009). Corporate political contributions: investment or agency? Working-paper, University of Minnesota. 
Ai, C. and E. C. Norton (2003). "Interaction terms in logit and probit models." Economic Letters 80: 123-129.

Alesina, A. (1988). "Credibility and Policy Convergence in a 2-Party System with Rational Voters." American Economic Review 78(4): 796-805.

Andrews, E. L. and E. Dash (2008). Insurers are getting in line for piece of federal bailout. The New York Times. New York.

Ansolabehere, S. and J. M. Snyder Jr (1999). "Money and institutional power." Texas Law Review 77: 1673-1704.

Barro, R. (1973). "The control of politicians: An economic model." Public Choice 14: 19-42.

Bayazitova, D. and A. Shivdasani (2009). Assessing TARP. Working paper, University of North Carolina.

Belsey, T. (2004). "Paying politicians: theory and evidence." Journal of the European Economic Association 2(2-3): 193-215.

Benmelech, E. and T. J. Moskowitz (2010). "The political economy of financial regulation: evidence from US state usury laws in the 19th century." Journal of Finance 65(3): 1029-1073.

Bhattacharya, U. and C. D. Marshall (2009). "Do They Do It for the Money?" SSRN eLibrary.

Brown, C. O. and I. S. Dinc (2005). "The politics of bank failures: evidence from emerging markets." Quarterly Journal of Economics 120(4): 1413-1444.

Buchanan, J. (1989). The public choice perspective. Essays on political economy, University of Hawaii Press.

Callander, S. (2008). "Political motivations." Review of Economic Studies 75(3): 671-697.

Claessens, S., E. Feijen and L. Laeven (2008). "Political connections and preferential access to finance: The role of campaign contributions." Journal of Financial Economics 88(3): 554-580.

Cohen, L., J. D. Coval and C. J. Malloy (2009). Do powerful politicians cause corporate downsizing. Working paper, Harvard Business School. Cambridge.

Committee on Standards of Official Conduct (2008). House Ethics Manual. Washington.

Committee on Standards of Official Conduct (2009). Highlights of the House Ethics Rules. Washington.

Cooper, M., H. Gulen and Ovtchinnikov (2010). "Corporate political contribution and stock returns." Journal of Finance 65(2): 687-724

Correia, M. M. (2009). Political connections, SEC enforcement and accounting quality. Working paper, Stanford University.

Denis, D. K. and J. J. McConnell (2003). "International Corporate Governance." Journal of Financial and Quantitative Analysis 38(01): 1-36.

Diermeier, D., M. Keane and A. Merlo (2005). "A political economy model of congressional careers." American Economic Review 95(1): 347-373.

Dinc, I. S. (2005). "Politicians and banks: Political influences on government-owned banks in emerging markets." Journal of Financial Economics 77(2): 453-479.

Duchin, R. and D. Sosyura (2009). TARP investments: Financials and Politics. Ross School of Business Working Paper. University of Michigan.

Faccio, M. (2006). "Politically connected firms." American Economic Review 96(1): 369-386.

Faccio, M., R. W. Masulis and J. J. McConnell (2006). "Political connections and corporate bailouts." Journal of Finance LXI(6): 2597-2635.

Ferraz, C. and F. Finan (2008). "Motivating Politicians: The Impacts of Monetary Incentives on Quality and Performance." SSRN eLibrary.

Fisman, R. (2001). "Estimating the value of political connections." American Economic Review 91(4): 1095-1102.

Fisman, R., D. Fisman, J. Galef and R. Khurana (2006). Estimating the value of connections to vicepresident Cheney. Working paper, Columbia University.

Goldman, E., J. Rocholl and J. So (2008). Political connections and the allocation of procurement contracts. Working paper, Indiana University.

Goldman, E., J. Rocholl and J. So (2009). "Do Politically Connected Boards Affect Firm Value?" Review of Financial Studies 22(6): 2331-2360.

Grieg, K. and M. Munger (1991). "Committee assignments, constituent preferences, and campaign contributions." Economic Inquiry 29: 29-43. 
Jayachandran, S. (2006). "The Jeffords Effect." Journal of Law and Economics 49: 397-425.

Kaiser, F. M., W. J. Oleszek, T. J. Halstead, M. Rosenberg and T. B. Tatelman (2007). Congressional oversight manual.

Kalt, J. A. and M. A. Zupan (1984). "Capture and ideology in the economic theory of politics." The American Economic Review 74: 279-300.

Kau, J. B., D. Keenan and P. H. Rubin (1982). "A general equilibrium model of congressional voting." Quarterly Journal of Economics 97(2): 271-293.

Khwaja, A. I. and A. Mian (2005). "Do lenders favor politically connected firms? Rent provision in an emerging financial market." Quarterly Journal of Economics 120(4): 1371-1411.

Knight, B. (2006). "Are policy platforms capitalized into equity prices? Evidence from the Bush/Gore 2000 Presidential Election." Journal of Public Economics 90(4-5): 751-773.

Kroszner, R. S. and P. Strahan (1996). "Regulatory incentives and the thrift crisis: dividends, mutualto-stock conversions, and financial distress." Journal of Finance 51(4): 1285-1320.

Kroszner, R. S. and T. Stratman (1998). "Interest-group competition and the organization of Congress: Theory and evidence from financial services' Political Action Committees." American Economic Review 88(5): 1163-1187.

Leuz, C., K. V. Lins and F. E. Warnock (2010). "Do Foreigners Invest Less in Poorly Governed Firms? (Reprinted from The Review of Financial Studies, vol 22, pg 3245-3285, 2009)." Review of Financial Studies 23(3): 3245-3285.

Leuz, C. and F. Oberholzer-Gee (2006). "Political relationships, global financing, and corporate transparency: Evidence from Indonesia." Journal of Financial Economics 81(2): 411-439.

Levitt, S. (1996). "How do Senators vote? Disentangling the role of voter preferences, party affiliation, and senator ideology." The American Economic Review 86(3): 425-441.

Levitt, S. D. (2006). "White-Collar Crime Writ Small: A Case Study of Bagels, Donuts, and the Honor System." The American Economic Review 96(2): 290-294.

Levitt, S. D. and S. J. Dubner (2005). Freakonomics. London, Allen Lane.

$\mathrm{Li}$, L. (2010). TARP funds distribution and bank loan growth. Working paper, Boston College.

McCormick, R. E. and R. D. Tollison (1981). Politicians, legislation, and the economy. Boston, Martinus Nijhoff.

McIntire, M. (2009). Bailout is a windfall to banks, if not to borrowers. The New York Times. New York.

Mian, A. R., A. Sufi and F. Trebbi (2010a). The political economy of the subprime mortgage credit expansion, University of California, NBER, and University of Chicago.

Mian, A. R., A. Sufi and F. Trebbi (2010b). "The Political Economy of the U.S. Mortgage Default Crisis." American Economic Review in press.

Milyo, J., D. Primo and T. Groseclose (2000). "Corporate PAC campaign contributions in perspective." Business and Politics 2(1): 5-14.

Peltzman, S. (1976). "Towards a more general theory of regulation?" Journal of Law and Economics 19: $211-241$.

Peltzman, S. (1984). "Constituent interest and congressional voting." Journal of Law \& Economics 27: $181-210$.

Poole, K. T. (2007). "Changing minds? Not in Congress." Public Choice 131(3-4): 435-451.

Poole, K. T. and H. Rosenthal (2007). Ideology and congress. Piscataway, NJ, Transaction Press.

Roberts, B. E. (1990). "A Dead Senator Tells No Lies: Seniority and the Distribution of Federal Benefits." American Journal of Political Science 34(1): 31-58.

Romer, T. and J. M. Snyder Jr (1994). "An empirical investigation of the dynamics of PAC contributions." American Journal of Political Science 38: 745-768.

Schneider, J. (2003). The committee system in the US congress. CRS Report for Congress.

Shleifer, A. and R. W. Vishny (1997). "A survey of corporate governance." Journal of Finance 52(2): 737-784.

SigTarp (2009a). Opportunities to strengthen controls to avoid undue external influence over capital purchase program decision-making.

SigTarp (2009b). Quarterly report to congress.

Stewart III, C. and J. Woon (2009). Congressional committee assignments, 103rd to 110th Congresses, 1993-2007: [House and Senate], [Updated to 01/03/2009]. 
Stigler, G. (1971). "The theory of economic regulation." Bell Journal of Economics and Management Science 2(Spring): 137-146.

Stigler, G. (1976). "The sizes of legislatures." Journal of Legal Studies 5(January): 17-34.

Stratmann, T. (2002). "Can special interests buy congressional votes? Evidence from financial services legislation." Journal of Law \& Economics XLV: 345-373.

Tullock, G. (1971). "The cost of transfers." Kyklos 4(December): 629-643.

Veronesi, P. and L. Zingales (2010). "Paulson's gift." Journal of Financial Economics 97(3): 339-368.

Weingast, B. R. (1984). "The congressional - bureaucratic system: A principal-agent perspective (with applications to the SEC)." Public Choice 44(1): 147-191.

Weingast, B. R. and M. J. Moran (1983). "Bureaucratic discretion or congressional control? Regulatory policymaking by the federal trade commission." Journal of Political Economy 91: 765-800.

Witman, D. A. (1977). "Candidates with policy preferences: a dynamic model." Journal of Economic Theory 14(1): 180-189.

Wooldridge, J. M. (2002). Econometric analysis of cross section and panel data. Cambridge, MA, MIT Press.

Yu, F. and X. Yu (2008). Corporate lobbying and fraud detection. Working paper, Indiana University.

Ziobrowski, A. J., P. Cheng, J. W. Boyd and B. J. Ziobrowski (2004). "Abnormal returns from the common stock investments of the US Senate." Journal of Financial and Quantitative Analysis 39(4): 1-16. 
T A B L E 1

\section{Summary Statistics of Characteristics of Financial Institutions Partitioned by Bailout Status}

Table 1 presents summary statistics of select financial characteristics for our sample of 555 financial institutions. We partition the sample into companies that received a government bailout under the Troubled Asset Relief Program before November 6, 2009 and those that did not. Bailout amount is the amount of TARP-funding committed by the Treasury in millions of dollars, Leverage is defined as total liabilities divided by total assets, Size is the market value of equity at the beginning of the year in millions of dollars, Book-to-market is the natural log of the ratio of book value of equity to market value of equity, measured at the beginning of the current fiscal year, Collateral is the ratio of property, plant, and equipment to total assets, Avgmktadjret is the average market adjusted daily returns measured over the first six months of 2008, and Stdret is the standard deviation of daily returns measured over the first six months of 2008. \%Closely held is the percentage of shares held by insiders, \%Inst. Ownership is the percentage of shares owned by institutions. All variables are winsorized at the $1 \%$ level. Also reported are Student's $t$-tests (Wilcoxon-tests) of the differences of means (medians) between the two samples.

\begin{tabular}{ccrrrrr}
\hline & \multicolumn{2}{c}{$\begin{array}{c}\text { Non-Bailout sample } \\
(\mathrm{N}=260)\end{array}$} & \multicolumn{3}{c}{$\begin{array}{c}\text { Bailout sample } \\
(\mathrm{N}=295)\end{array}$} \\
\hline & \multicolumn{1}{c}{ Mean } & St. Dev. & Median & Mean & St. Dev. & Median \\
\hline Collateral & $0.015^{*}$ & 0.010 & $0.013 * *$ & 0.017 & 0.010 & 0.015 \\
Leverage & 0.900 & 0.049 & 0.911 & 0.905 & 0.026 & 0.906 \\
Size & $2,210.939 *$ & $9,920.667$ & $140.185 * *$ & $4,233.917$ & $15,820.008$ & 194.331 \\
Book-to-market & $-0.079^{* *}$ & 0.658 & $-0.153 * *$ & -0.231 & 0.337 & -0.224 \\
Avgmktadjret & $-0.038^{* *}$ & 0.229 & $0.015 * * *$ & -0.100 & 0.233 & -0.054 \\
Stdret & 0.031 & 0.013 & $0.028 * *$ & 0.032 & 0.010 & 0.031 \\
\%Closely held & $22.471^{* * *}$ & 22.175 & $15.658 * * *$ & 13.692 & 14.525 & 8.876 \\
\%Inst. ownership & $23.049 * * *$ & 22.414 & $14.898 * * *$ & 34.027 & 24.158 & 28.867 \\
Bailout amount & & & & $1,110.000$ & $6,130.000$ & 39.000 \\
\hline
\end{tabular}


T A B L E 2

\section{Determinants of the Voting Behavior of Members of Congress on Bailout Legislation}

Table 2 presents our regressions for predicting how Congress members will vote on H.R. 3997 and H.R. 1424. The House voted on H.R. 3997 on September 29, 2008, the Senate on H.R. 1424 on October 1, 2008, and the House on H.R. 1424 on October 3, 2008. We regress an indicator variable that takes the value of one if a member votes in favor of the proposed bill and zero otherwise onto measures of total equity ownership held by that member in our sample firms and our control variables. We draw our data on firms' donations to politicians and their equity ownership in these firms from the Center for Responsive Politics, and on each politician's voting record from the Clerk of the House or the Bill Clerk of the Senate. We draw our employment data on each state's financial sector from the Bureau of Labor Statistics and our election margin data from the Federal Election Commission. Equity ownership in financial sector is the log of a politician's total ownership in our sample firms, Equity ownership in S\&P500 is the log of a politicians total ownership in S\&P 500 firms excluding financial institutions, Expected losses due to ownership in financial sector is the log of the number of shares a politician holds in our sample firms at the beginning of 2008 multiplied by the change in the stock price of each of these shares on September 29, Expected losses due to ownership in S\&P 500 firms is the log of the number of shares in non-financial S\&P 500 firms at the beginning of 2008 multiplied by the change in stock price of each share on September 29, Long-term PAC donations by financial sector is the log of our sample firms' total donations to a politician in any federal election campaign between 2003-2008, , Seniority is the number of years since the date a politician was first elected to Congress, Importance of financial sector to home state is the total number of employees in a state's financial activities sector (seasonally adjusted) divided by the total number of employees in all sectors in the same state (seasonally adjusted), Ideology score is the first dimension of the DW-Nominate representative ideology score for each politician based on past voting record in the $110^{\text {th }}$ Congress, and Election margin is a politician's margin of victory over his or her closest competitor in the most recent congressional election. Robust standard errors are in parentheses. *, **, and *** denote significance at the $10 \%, 5 \%$, and $1 \%$ levels (two-tailed).

\section{Panel A: Summary statistics on characteristics of members of Congress}

\begin{tabular}{crrrr}
\hline Variable & \multicolumn{2}{c}{ House of Representatives } & \multicolumn{2}{c}{ Senate } \\
\cline { 2 - 5 } & Mean & Std. & Mean & Std. \\
\hline Equity ownership in financial sector (in \$000) & 112.66 & 984.84 & 206.93 & $1,190.12$ \\
Equity ownership in S\&P500 (in \$000) & $1,037.74$ & $10,069.67$ & 875.22 & $6,440.01$ \\
Expected losses due to ownership in financial sector & $11,712.69$ & $97,282.95$ & $22,038.09$ & $126,787.09$ \\
Expected losses due to ownership in S\&P500 & $40,500.09$ & $352,069.36$ & $49,530.96$ & $349,434.63$ \\
Long-term PAC donations by financial sector (in \$000) & 39.84 & 60.24 & 71.52 & 58.68 \\
$=1$ if Republican & 0.46 & 0.50 & 0.48 & 0.50 \\
Seniority & 11.68 & 8.55 & 15.36 & 10.73 \\
Importance of financial sector in home state & 0.06 & 0.01 & 0.06 & 0.02 \\
Election margin & 35.63 & 26.25 & 26.05 & 20.41 \\
Ideology score & 0.04 & 0.51 & -0.01 & 0.47 \\
\hline
\end{tabular}


Panel B: Logit regressions of the vote on legislative proposals by members of Congress

Logit regressions

$(1=$ Aye, $0=$ No $)$

House vote on H.R. 3997 (Sept. Senate vote on H.R. 1424 (Oct. $\quad$ House vote on H.R. 1424 (Oct.

House vote on H.R. 1424 (Oct.

$$
\text { 3, 3008) }
$$

(1) -12 -

$1,2008)$

$3,2008)$

(7)

(8)

Equity ownership in financial sector

Equity ownership in S\&P500

Expected losses due to ownership in financial sector

Expected losses due to ownership in

$$
\text { S\&P500 }
$$

Long-term PAC donations by financial sector

Election margin

$$
\begin{aligned}
& \text { Seniority } \\
= & 1 \text { if Republican }
\end{aligned}
$$

Ideology score

Importance of financial sector in home

$$
\text { state }
$$

$\begin{array}{cc}0.075 * * * & 0.107 * * * \\ (0.027) & (0.033) \\ -0.015 & -0.028 \\ (0.023) & (0.027)\end{array}$

0.008

$(0.057)$

$-0.002$

(0.053)

$0.096 * *$

(0.042)

$-0.011$

(0.035)

$0.081 * \quad 0.105 * \quad 0.108 * *$

$\begin{array}{lll}(0.049) & (0.055) & (0.054)\end{array}$

$\begin{array}{lll}0.001 & -0.003 & -0.003\end{array}$

$\begin{array}{lll}(0.005) & (0.006) \quad(0.006)\end{array}$

$0.047 * * * \quad 0.053^{* * *} \quad 0.051^{* * *}$

$\begin{array}{lll}(0.014) & (0.015) & (0.015)\end{array}$

$\begin{array}{lll}-0.731 & -1.526 * & -1.444 *\end{array}$

(0.665)

$-0.458$

(0.678)

$25.969 * * *$

(10.046)

0.179

(0.128)

$-0.021$

(0.014)

$0.094 * * *$

(0.029)

1.999

(0.832) (0.831)

0.175

0.114

(0.877) (0.870)

(2.039)

$-2.634$

(2.414)

(24.924)

(2) (3)

(5)

(6)

$0.065 * *$

$0.065^{* *}$
$(0.027)$

$-0.013$

(0.022)

$-0.011$

$(0.072)$

0.011

(0.072)

$70.286^{* * *}$
0.179

(0.127)

$-0.021$

$0.095^{* * *}$

(0.029)

1.961

(2.028)

$-2.589$

(2.401)

$70.536 * * *$

(24.869)
(0.014)

21.091**

(10.034)

0.030

(0.041)

$-0.004$

(0.033)

$0.067 * *$

(0.033)

$-0.007$

(0.029)

$0.109 * *$

(0.047)

0.003

$(0.005)$

0.021

(0.014)

0.257

(0.703)

$-1.542 * *$

(0.747)

19.753*

(10.744)

No

No
434
50.95
0.000

No
434
48.04
0.000

No
228

16.97

0.030

0.046

(0.050)

$-0.007$

(0.044)

0.161 **

$0.161 * *$

(0.077)

(0.077)

0.007

(0.007)

(0.007)

$-0.046 *$

$-0.045 *$

(0.027)

(0.027)

(1.039)

$-2.682 * *$

1.678

(1.038)

$-2.683^{* *}$

(1.061)

(1.060)

13.274

(14.343)

57.45

0.000

0.000

0.041

0.046

0.000

No
228

17.00 
Panel C: Voting and personal financial interests: The effect of the sensitivity of a politician's wealth to the financial sector

For both House and Senate, we divide our sample of politicians in two groups: those who voted in favor of the initial bailout proposal (Vote=Aye) and those who voted against (Vote=No). For each group, we regress the annual percentage change in wealth (using total assets as our deflator) onto the annual percentage change in the S\&P North American Financial Services Sector Index. We use personal financial disclosure data from 2004-2007. Sensitivity of wealth to financial sector 2004-2007 is the coefficient estimate taken from this regression. $P$-values are based on robust standard errors. Median (mean) dollar wealth effect is computed by using the median (mean) value of assets of politicians at the beginning of 2008.

\begin{tabular}{ccccc}
\hline & \multicolumn{2}{c}{ House of Representatives } & \multicolumn{2}{c}{ Senate } \\
\cline { 2 - 5 } & Vote & Vote $=$ & Vote $=$ & \multicolumn{2}{c}{ Vote $=$} \\
Aye & No \\
\hline Sensitivity of wealth to financial sector 2004-2007 & Aye & No & Aye \\
$\quad p$-value & 0.530 & -0.380 & -0.030 & 0.510 \\
Median dollar wealth effect of 10\% increase in financial & 0.047 & 0.808 & 0.921 & 0.345 \\
$\quad$ sector index & & & & - \\
Mean dollar wealth effect of 10\% increase in financial \\
sector index
\end{tabular}

\section{Panel D: Constituent or personal financial interests: Investments in home state financial institutions}

The panel presents summarized versions of the voting regressions reported in Panel B in which we distinguish between home-state and out-of-state ownership in the financial sector. We replace the original Equity ownership in financial sector by two variables: $=1$ if investor in home state (out-of-state) financial institutions, which is an indicator variable that takes the value of one if a politician holds ownership in financial institutions in (outside of) his/her home state, and zero otherwise. We augment the regression by including Number of financial institutions in (outside of) home state owned, which is the log of the number of financial institutions in (outside of) a politician's home state in which a politician has ownership.

\begin{tabular}{lcc}
\hline Logit regressions $(1=$ Aye, $0=$ No) & House vote on H.R. 3997 (Sept. & House vote on H.R. 1424 (Oct. \\
\end{tabular}

\begin{tabular}{lcc} 
Long-term PAC donations by financial sector & $0.081^{*}$ & $0.107^{* *}$ \\
& $(0.049)$ & $(0.047)$ \\
& $26.341^{* * *}$ & $22.064^{* *}$ \\
Importance of financial sector in home state & $(9.320)$ & $1.263)$ \\
& 1.822 & $(1.261)$ \\
= 1 if investor in home state financial sector & $(1.189)$ & $0.897^{*}$ \\
= 1 if investor in out-of-state financial sector & $1.151^{* *}$ & $(0.477)$ \\
\# of financial institutions in home state owned & $(0.460)$ & -0.419 \\
$\quad$ by politician & -0.997 & $(1.490)$ \\
\# of financial institutions out-of-state owned & $(1.380)$ & -0.261 \\
$\quad$ by politician & -0.465 & $(0.350)$ \\
\hline Controls included & $(0.337)$ & Yes \\
Observations & Yes & 434 \\
Chi-squared & 433 & 56.570 \\
p-value & 63.830 & 0.000
\end{tabular}


Panel E: Ideology vs. economic incentives: relative roles of constituent, special, and personal financial interests

The panel relies on logit regressions of an indicator variable that takes the value of one if a member votes in favor of the proposed bill and zero otherwise onto Equity ownership in financial sector, Long-term PAC donations by financial sector, Importance of financial sector, Ideology score, and the interaction of Ideology score with each of these variables, as well as our full set of control variables. We report the marginal effect (i.e., the change in the likelihood that a politician votes in favor of the proposal for a change in the variable of interest) at different value of Ideology score (the interaction variable), that is, at the sample minimum, median, and maximum, while holding all other variables constant at the mean. High ideology scores indicate more conservative politicians.

\begin{tabular}{|c|c|c|c|c|c|c|}
\hline \multirow[b]{2}{*}{$\begin{array}{l}\text { Ideology score } \\
\text { at: }\end{array}$} & \multicolumn{3}{|c|}{$\begin{array}{l}\text { House vote on H.R. } 3997 \text { (Sept. 29, 2008) } \\
\frac{\text { Average marginal effect of: }}{\text { Long term }}\end{array}$} & \multicolumn{3}{|c|}{$\begin{array}{l}\text { House vote on H.R. } 1424 \text { (Oct. 3, 2008) } \\
\text { Average marginal effect of: }\end{array}$} \\
\hline & $\begin{array}{l}\text { Equity } \\
\text { ownership in } \\
\text { financial } \\
\text { sector } \\
\text { (1) }\end{array}$ & $\begin{array}{l}\text { Long term } \\
\text { PAC } \\
\text { donations by } \\
\text { financial } \\
\text { sector } \\
\text { (2) }\end{array}$ & $\begin{array}{l}\text { Importance of } \\
\text { financial } \\
\text { sector } \\
\text { (3) }\end{array}$ & $\begin{array}{l}\text { Equity } \\
\text { ownership in } \\
\text { financial } \\
\text { sector } \\
\text { (4) }\end{array}$ & $\begin{array}{l}\text { Long term } \\
\text { PAC } \\
\text { donations by } \\
\text { financial } \\
\text { sector } \\
\text { (5) }\end{array}$ & $\begin{array}{l}\text { Importance of } \\
\text { financial } \\
\text { sector } \\
(6)\end{array}$ \\
\hline $\begin{array}{l}\text { Minimum } \\
\text { (Liberal) }\end{array}$ & $0.200 * *$ & 0.024 & $14.535^{* * *}$ & 0.009 & $0.018^{*}$ & $6.897 * *$ \\
\hline Median & $0.200 * * *$ & $0.020^{*}$ & $7.616^{* * *}$ & $0.015^{* *}$ & $0.023 * *$ & $5.833 * * *$ \\
\hline $\begin{array}{c}\text { Maximum } \\
\text { (Conservative) }\end{array}$ & 0.003 & -0.002 & $-7.94^{*}$ & 0.008 & 0.003 & -5.016 \\
\hline
\end{tabular}


T A B L E 3

Summary Statistics on Congressional Equity Ownership, Campaign Contributions, and "Political" Boards of Directors of (Non-) Bailout Financial Institutions

Table 3 presents summary statistics of measures of equity ownership, campaign contributions, and the presence of (former) politicians on the Board of Directors for our sample of 555 financial institutions. We partition the sample into companies that received a government bailout under the Troubled Asset Relief Program before November 6, 2009 and those that did not. Total long term PAC donations is the dollar amount of Political Action Committee contributions a firm makes to either the Democratic or Republican Party in the election cycles 2003-2008, \# of candidates receiving PAC donations is the number of Democratic or Republican candidates for Federal elections to whom the firm makes Political Action Committee contributions in the cycle 2007-2008, Total lobby expenses is the firm's expenditure on lobbying in the election cycle 2007-2008, Equity ownership is the summed equity ownership of all members of Congress in firm $i$, \# of investors is the number of members of Congress who own equity in firm $i$, \# of Dem (Rep) board members is the number of members on the board of directors that are currently in an elected position on behalf of the Democratic (Republican) Party or that held such a position in the past. We obtain data on PAC donations, lobby expenditures, and equity ownership from the Center for Responsive Politics. Board membership data is from SEC form DEF 14A. We assess the differences in means using the Student's $t$-test. We assess the differences in the proportion of positive values between the two samples using a z-test. We indicate whether the differences between the corresponding mean and proportion of positive values are significant at the $10 \%, 5 \%$, and $1 \%$ levels using $*$, **, and ${ }^{* * *}$, respectively.

\begin{tabular}{|c|c|c|c|c|c|c|}
\hline & \multicolumn{3}{|c|}{$\begin{array}{l}\text { Non-Bailout sample } \\
\qquad(\mathrm{N}=260)\end{array}$} & \multicolumn{3}{|c|}{$\begin{array}{l}\text { Bailout sample } \\
\qquad(\mathrm{N}=295)\end{array}$} \\
\hline & Mean & $\begin{array}{l}\text { St. } \\
\text { Dev. }\end{array}$ & $\begin{array}{l}\% \text { of } \\
\text { firms } \\
>0\end{array}$ & Mean & St. Dev. & $\begin{array}{c}\% \text { of } \\
\text { firms }>0\end{array}$ \\
\hline \multicolumn{7}{|l|}{ Equity ownership (in \$000): } \\
\hline -Powerful committee members & $0.11 * * *$ & 0.84 & $3.10 * * *$ & 55.44 & 301.2 & 9.5 \\
\hline -Non-powerful committee members & 6.62 & 72.66 & 9.20 & 6.71 & 355.13 & 14.2 \\
\hline $\begin{array}{c}\text {-Non-committee members } \\
\text { \# of investors: }\end{array}$ & $14.36 * *$ & 56.57 & 15.30 & 155.26 & 1057.24 & 19.3 \\
\hline -Powerful committee members & $0.03 * * *$ & 0.20 & $3.10 * * *$ & 0.22 & 0.9 & 9.8 \\
\hline -Non-powerful committee members & 0.19 & 0.72 & 9.20 & 0.32 & 1.07 & 12.5 \\
\hline -Non-committee members & $0.34 * * *$ & 1.15 & 15.80 & 1.16 & 4.47 & 20.3 \\
\hline $\begin{array}{c}\text { Total long-term PAC donations (in } \\
\$ 000 \text { ) } \\
\text { \# of candidates receiving PAC } \\
\text { donations }\end{array}$ & $\begin{array}{c}19.13^{* *} \\
3.18 * *\end{array}$ & 133.43 & $10.77 * *$ & 65.99 & 298.97 & 18.3 \\
\hline Total lobby expenses (in \$000) & 165.02 & 969.34 & $5.80 * *$ & 348.73 & 1927.2 & 10.5 \\
\hline \# of Dem board members & 0.01 & 0.15 & & 0.02 & 0.15 & \\
\hline \# of Rep board members & $0.02 *$ & 0.15 & & 0.05 & 0.22 & \\
\hline
\end{tabular}


T A B L E 4

Committee-level Analyses: Equity Ownership by Committee Members in Financial Institutions, the Bailout Amount Committed, and the Timing of the Commitment

Table 4 presents analyses of the equity ownership in financial institutions held by members of congressional committees with jurisdiction over TARP. We first present logit regressions of an indicator variable that takes the value of one if the firm was bailed out under TARP and zero otherwise onto measures of summed equity ownership by committee members (Panel A). Panel B presents Tobit regressions of the bailout amount committed onto measures of summed equity ownership held by committee members. Panel B also presents Cox proportional hazard regressions of the hazard rate (i.e., time until bailout) onto measures of the summed equity ownership. In Panel C, we document the effect of a firm having equity ownership by a committee member who represents the state in which the firm is headquartered (Ownership in firms in home state). In this panel, we also control for Ownership in firms out-of-home state and the Percentage of investors among committee members from same state as firm. We collect personal finance data provided by the Center for Responsive Politics and sum the equity ownership of members seated on congressional committees with jurisdiction over TARP. Specifically, we consider the Financial Services committee in the House of Representatives, the Banking, Housing, and Urban Affairs committee and the Finance committee of the Senate. We also combine the equity ownership of all members in any one of these committees in the variable Ownership Combined Congressional Committees. We use in the regressions the logarithm of the summed ownership of all committee members in firm $i$ at the beginning of 2008. We also count the number of equity owners in sample firms in each of these three committees as well as the total number of Congress members who own equity in financial institutions across all three committees. Total PAC donations (Total number of PAC recipients) is the residual of a regression of the total PAC donations made to Federal election candidates (i.e., the log of the total number of PAC recipients) by firm $i$ in the 2003-2008 (2007-2008) election cycles onto the summed ownership of all committee members in firm $i$ (i.e., the log of the total number of investors among committee members). Total non-committee ownership (total number of non-committee investors) is the log of summed ownership by all non-committee Congress members in firm $i$ (i.e., the log of the total number of investors among non-committee members). Dem (Rep) board is the number of board members who are (former) politicians for the Democratic (Republican) Party. Our sample includes 555 financial institutions, and we consider bailouts under the Troubled Asset Relief Program. We obtain the dates of the bailout and the bailout amount committed from ProPublica.org. We include (but, except in Panel A, omit the details of) the following control variables: Leverage is defined as total liabilities divided by total assets, Size is the logarithm of the market value of equity at the beginning of the year, Book-to-market is the book value of equity scaled by market capitalization at the beginning of the year, Collateral is the ratio of property, plant, and equipment to total assets, Avgmktadjret is the average market adjusted daily returns measured over the first six months of 2008, Stdret is the standard deviation of daily returns measured over the first six months of 2008, \%Closely held is the percentage of shares held by insiders, and \%Inst. Ownership is the percentage of shares owned by institutions; we also include an indicator variable for firms in the insurance industry (SIC 67). The coefficients in the Cox regressions are reported in unexponentiated form. Robust standard errors are in parentheses. *, **, and *** denote significance at the $10 \%, 5 \%$, and $1 \%$ levels (two-tailed). 
Panel A: Logit regressions of bailout status onto equity ownership of members of specific congressional committees and number of investors in these congressional committees in 2008

\begin{tabular}{|c|c|c|c|c|c|c|c|c|}
\hline \multirow{2}{*}{$\begin{array}{c}\text { Dependent variable: } \\
\text { Bailed out? indicator }\end{array}$} & (1) & $(2)$ & (3) & (4) & (5) & (6) & (7) & (8) \\
\hline & \multicolumn{4}{|c|}{ Equity ownership } & \multicolumn{4}{|c|}{ \# of investors } \\
\hline Size & -0.018 & -0.028 & -0.105 & -0.127 & -0.107 & -0.094 & $-0.177^{*}$ & $-0.175^{*}$ \\
\hline & $\begin{array}{c}\text { (0.095) } \\
051 * * *\end{array}$ & $\begin{array}{l}(0.089) \\
073 * * *\end{array}$ & $(0.103)$ & $(0.108)$ & (0.099) & $(0.095)$ & $\begin{array}{l}(0.103) \\
0.998 * * *\end{array}$ & $\begin{array}{c}(0.104) \\
-0.940 * * *\end{array}$ \\
\hline Bоoк-to-market & $\begin{array}{c}-0.851 \\
(0.211)\end{array}$ & $\begin{array}{c}-0.823 \\
(0.202)\end{array}$ & $\begin{array}{c}-0.830^{2} \\
(0.204)\end{array}$ & $\begin{array}{c}-0.912 \\
(0.209)\end{array}$ & $\begin{array}{c}-0.8611^{2} \\
(0.213)\end{array}$ & $\begin{array}{c}-0.84 / \\
(0.207)\end{array}$ & $\begin{array}{c}-0.898 \\
(0.210)\end{array}$ & $\begin{array}{c}-0.940 \\
(0.212)\end{array}$ \\
\hline Avgmktadjret & -0.584 & -0.562 & -0.586 & -0.626 & -0.555 & -0.533 & -0.594 & -0.616 \\
\hline & $(0.502)$ & $(0.498)$ & $(0.497)$ & $(0.498)$ & $(0.501)$ & $(0.496)$ & (0.499) & $(0.498)$ \\
\hline Collateral & $17.704 *$ & $16.490 *$ & 17.652* & 17.043* & 15.643 & 14.890 & $16.339 *$ & 15.624 \\
\hline & (9.777) & (9.923) & (9.785) & (9.778) & (9.833) & (9.938) & (9.851) & (9.833) \\
\hline Leverage & 3.329 & 3.696 & 3.021 & 3.136 & 3.022 & 3.304 & 2.666 & 2.844 \\
\hline & (2.775) & (2.751) & (2.617) & (2.652) & (2.753) & (2.744) & (2.644) & (2.706) \\
\hline Stdret & 9.356 & 8.355 & 6.854 & 6.835 & 8.096 & 7.803 & 6.174 & 6.841 \\
\hline & (9.696) & (9.699) & $(9.477)$ & (9.522) & (9.659) & (9.659) & $(9.440)$ & (9.558) \\
\hline \% Closely held & $-0.023 * * *$ & $-0.023 * * *$ & $-0.024^{* * *}$ & $-0.024 * * *$ & $-0.022 * * *$ & $-0.023 * * *$ & $-0.023 * * *$ & $-0.023 * * *$ \\
\hline & $(0.005)$ & $(0.005)$ & $(0.005)$ & $(0.005)$ & $(0.005)$ & $(0.005)$ & $(0.005)$ & $(0.005)$ \\
\hline \% Inst. Ownership & $0.017 * * *$ & $0.017 * * *$ & $0.019 * * *$ & $0.017 * * *$ & $0.018 * * *$ & $0.018^{* * *}$ & $0.020 * * *$ & $0.019 * * *$ \\
\hline & $(0.005)$ & $(0.005)$ & $(0.006)$ & $(0.005)$ & $(0.005)$ & $(0.005)$ & $(0.006)$ & $(0.005)$ \\
\hline Dem board & 0.862 & $0.913^{*}$ & 0.855 & 0.791 & 0.659 & 0.725 & 0.727 & 0.631 \\
\hline & $(0.574)$ & $(0.553)$ & $(0.576)$ & $(0.553)$ & $(0.570)$ & $(0.562)$ & $(0.594)$ & $(0.572)$ \\
\hline Rep board & $1.046^{*}$ & $1.042^{*}$ & $0.949^{*}$ & $0.986^{*}$ & $0.962 *$ & $0.970^{*}$ & $0.921 *$ & $0.969^{*}$ \\
\hline & $(0.545)$ & $(0.550)$ & $(0.536)$ & $(0.535)$ & $(0.544)$ & $(0.547)$ & $(0.541)$ & $(0.541)$ \\
\hline $\begin{array}{l}\text { Total number of PAC } \\
\text { recipients }\end{array}$ & & & & & $\begin{array}{c}0.204 \\
(0.152)\end{array}$ & $\begin{array}{c}0.193 \\
(0.145)\end{array}$ & $\begin{array}{l}0.309 * \\
(0.164)\end{array}$ & $\begin{array}{l}0.329 * \\
(0.168)\end{array}$ \\
\hline $\begin{array}{l}\text { Total number of non- } \\
\text { committee investors }\end{array}$ & & & & & $\begin{array}{c}0.339 \\
(0.287)\end{array}$ & $\begin{array}{c}0.195 \\
(0.323)\end{array}$ & $\begin{array}{c}0.036 \\
(0.315)\end{array}$ & $\begin{array}{c}0.002 \\
(0.343)\end{array}$ \\
\hline Total PAC donations & $\begin{array}{c}0.025 \\
(0.033)\end{array}$ & $\begin{array}{c}0.021 \\
(0.032)\end{array}$ & $\begin{array}{c}0.051 \\
(0.036)\end{array}$ & $\begin{array}{c}0.056 \\
(0.037)\end{array}$ & & & & \\
\hline Total non-committee & -0.016 & -0.021 & -0.026 & -0.028 & & & & \\
\hline ownership & $(0.030)$ & $(0.030)$ & $(0.030)$ & $(0.031)$ & & & & \\
\hline $\begin{array}{c}\text { Senate Banking, Housing } \\
\text { and Urban Affairs } \\
\text { committee }\end{array}$ & $\begin{array}{c}0.086 \\
(0.060)\end{array}$ & & & & $\begin{array}{c}0.500 \\
(0.613)\end{array}$ & & & \\
\hline $\begin{array}{c}\text { Senate Finance } \\
\text { committee }\end{array}$ & & $\begin{array}{c}0.165^{* * *} \\
(0.063)\end{array}$ & & & & $\begin{array}{l}1.336^{*} \\
(0.729)\end{array}$ & & \\
\hline $\begin{array}{c}\text { House Financial Services } \\
\text { committee }\end{array}$ & & & $\begin{array}{l}0.143^{* *} \\
(0.060)\end{array}$ & & & & $\begin{array}{l}1.508^{* *} \\
(0.644)\end{array}$ & \\
\hline $\begin{array}{c}\text { Combined congressional } \\
\text { committees }\end{array}$ & & & & $\begin{array}{c}0.135^{* *} \\
(0.054)\end{array}$ & & & & $\begin{array}{l}1.069^{* *} \\
(0.473)\end{array}$ \\
\hline $\mathrm{N}$ & 555 & 555 & 555 & 555 & 555 & 555 & 555 & 555 \\
\hline F-statistic & 97.084 & 99.167 & 91.825 & 94.240 & 102.871 & 105.706 & 93.464 & 99.954 \\
\hline$p$-value & 0.000 & 0.000 & 0.000 & 0.000 & 0.000 & 0.000 & 0.000 & 0.000 \\
\hline
\end{tabular}


Panel B: Tobit regressions of bailout amount and Cox proportional hazard regressions onto the dollar amount of equity ownership in financial institutions by congressional committee members in 2008

Tobit regressions of bailout amount Cox proportional hazard regressions (1) (2)

(3)

(4)

(5)

(6)

(7)

(8)

Dem board

Rep board

Total PAC donations

Total non-committee ownership

Senate Banking, Housing and Urban Affairs committee

Senate Finance committee

House Financial Services committee

$5.4665 .458 *$

5.466
$(3.482)$

(3.177)

5.321

5.177

$0.939 * * *$

$1.068 * * *$

$0.974^{* * *} \quad 0.982^{* * *}$

$5.825 * * \quad 5.762 * *$

(3.526)

(3.482)

(0.325)

(0.285)

(0.307)

(0.314)

(2.700)

(2.701)

(2.677)

$5.668 * 0.511^{* *}$

$0.490 * *$

$0.439 *$

$0.466^{* *}$

0.201

0.202

0.362

(2.655) (0.234)

$(0.232)$

$(0.229)$

$(0.224)$

$\begin{array}{ll}(0.216) & (0.215)\end{array}$

$(0.222)$

$0.397 *$

$0.038^{*}$

$0.035 *$

$0.043^{* *}$

0.050 **

$-0.080-0.116$

$-0.148$

(0.231)

(0.020)

(0.019)

(0.020)

$(0.020)$

$\left(\begin{array}{ll}0.204) & (0.207)\end{array}\right.$

(0.203)

$-0.173$

0.004

0.001

$-0.001$

$-0.004$

0.463
$(0.374)$

$0.635^{* *}$

(0.263)

$$
\begin{gathered}
0.814 * * * \\
(0.303)
\end{gathered}
$$

$0.077^{*}$

$(0.042)$

$0.081^{* *}$

(0.037)

$0.072 * *$

(0.032)

Combined congressional committees

Controls included?

$\mathrm{N}$

F-statistic

$p$-value Panel C: Analysis of the effect of the presence
institution headquartered in their home state

\section{Logit regressions of Tobit regressions of \\ Bailed out?indicator \\ Amount of bailout}

(1) (2) (3) (4)

Combined congressional

committees:

- Ownership in firms in

home state

0.153

(0.125)

$-0.020$

$0.678 * *$

(0.320)

$-0.028$

(0.327)

0.059

(0.052)

0.028

- Ownership in firms out-of-

$0.125^{* *}$

(0.056)

$0.135^{* *} \quad 0.615^{* *}$

$0.714^{* *}$

0.062*

(0.318)

(0.033)

0.066 *

(0.059)

(0.308)

\subsection{4}

(1.548)

$12.175^{* *}$

(5.870)

0.539

(1.390)

committee members from same

state as firm

\section{Controls included?}

PAC donations and political board variables included?

$N$

$p$-value

$\begin{array}{ccc}\text { Yes } & \text { Yes } & \text { Yes } \\ \text { Yes } & \text { Yes } & \text { Yes } \\ 555 & 555 & 547 \\ 0.000 & 0.000 & 0.000\end{array}$

\begin{tabular}{lc} 
Yes & Yes \\
Yes & Yes \\
& \\
547 & 547 \\
.000 & 0.000 \\
\hline
\end{tabular}

Yes

547

0.000

0.000

0.000

Yes

Yes
Yes

Yes

Yes

555

0.000

555

0.000 
T A B L E 5

The Influence of Equity Ownership Held by Powerful Members of Congress

Table 5 presents analyses of the equity ownership in financial institutions held by powerful and non-powerful members of congressional committees with jurisdiction over TARP. Powerful politicians are those who chair a congressional (sub)committee with jurisdiction over TARP or are the ranking member of such a (sub)committee. The table reports Tobit regressions of the amount of bailout committed onto measures of the sum of the equity ownership held by powerful and non-powerful committee members. The table also presents Cox proportional hazard regressions of the hazard rate (i.e., time until bailout) onto measures of the summed equity ownership by powerful and other politicians. We collect personal finance data provided by the Center for Responsive Politics and sum the equity ownership of chairpersons and ranking members in congressional (sub)committees with jurisdiction over TARP. Specifically, we consider the Financial Services committee in the House of Representatives, the Banking, Housing and Urban Affairs and Finance committees in the Senate, and their subcommittees. We also combine the equity ownership of all members in any one of these committees in the variable Ownership Combined Congressional Committees. We use in our regressions the logarithm of the sum of the ownership held by all powerful committee members in firm $i$ in 2008. Total PAC donations is the residual of a regression of the total PAC donations made to Federal election candidates by firm $i$ in the 2003-2008 election cycles onto the sum of the ownership held by all committee members in firm $i$ in 2008. Total non-committee ownership is the sum of the ownership held by all non-committee Congress members in firm $i$ in 2008. Dem (Rep) board is the number of board members who are (former) politicians for the Democratic (Republican) Party. Our sample includes 555 financial institutions, and we consider bailouts under the Troubled Asset Relief Program. We obtain the dates of each firm's bailout and the amount of bailout committed from ProPublica.org. We include (but omit the details of) the same set of control variables as in Table 4. The coefficients in the Cox regressions are reported in unexponentiated form. Robust standard errors are in parentheses. ${ }^{*}, * *$, and ${ }^{* * *}$ denote significance at the $10 \%, 5 \%$, and $1 \%$ levels (two-tailed).

Dollar amount of equity ownership held by powerful members

Tobit regressions of bailout amount Cox proportional hazard regressions
(1)
(2)
(3)
(4)
(5)
(6)
(7)
(8)

Total PAC donations

Total non-committee politician ownership

Senate Banking committee: Nonpowerful members
0.156

$(0.218)$

0.199

0.276

0.293

0.031

0.032

$0.041^{* *}$

$0.048^{* *}$

(0.215)

(0.217)

$(0.229)$

(0.021)

(0.019)

(0.020)

$(0.020)$

$-0.070$

$-0.117$

$-0.123$

$-0.196$

0.011

0.001

0.001

(0.211)

$(0.018)$

(0.018)

(0.018)

0.031

(0.047)

(0.368)

Senate Banking committee: Powerful members

$1.176^{* * *}$

(0.417)

0.506

(0.436)

$0.580^{* *}$

(0.265)

$0.144^{* * *}$

(0.056)

Senate Finance committee: Nonpowerful members

Senate Finance committee: Powerful members

House Financial Services committee: Non-powerful members

House Financial Services committee: Powerful members

Combined congressional committees: Non-powerful members

Combined congressional committees: Powerful members

Controls included? Political board variables included?

F-statistic $\mathrm{N}$

$p$-value $\mathrm{N}$

p-value

rat

a.

